\title{
الحرية و إرادة الفعل \\ في الأنثروبولوجيا الفلسفية
}

$$
\begin{aligned}
& \text { الأستاذ الدكتور / محمد عباس إبراهيم } \\
& \text { أستاذ الأنثروبولوجيا - كلية الآداب } \\
& \text { جامعة الإسكندرية }
\end{aligned}
$$


يدخل في نطاق وحيز الأنثروبولوجيا الفلسفية التوجه المنهجي الخسـدد لاســيفاء البراهين والدلالة على صحة الافتراضات المنبثقة عن النظريات العلمية، فيشكل المنــــهج

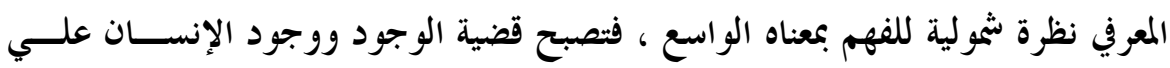

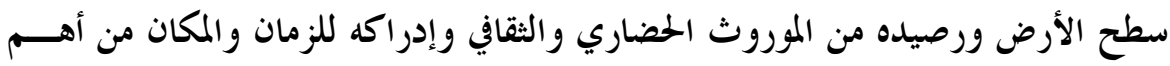

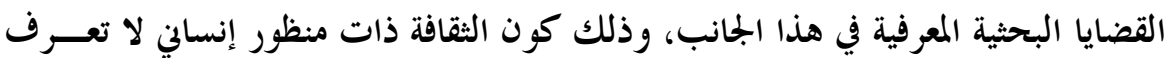

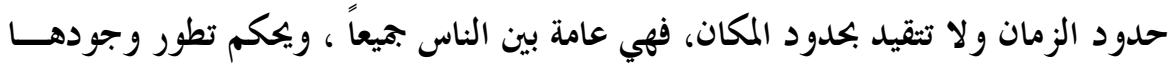

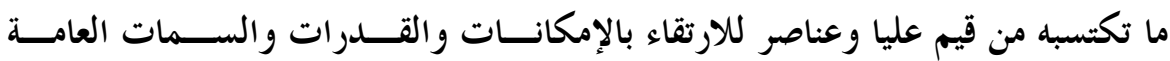
للإنسانية، كما تعني الأنثروبولوجيا الفلسفية بدراسة التفكير المنطقي للارتباط المتلازم بين

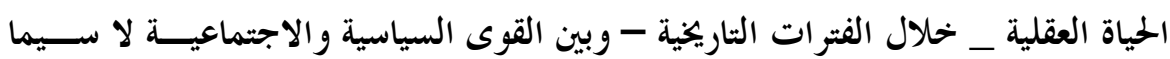
حين تتبدل أسس التفكير الإنساني نتيجة لتبدل الجذذور الاجتماعية المعرفية الإنسانية الــتي

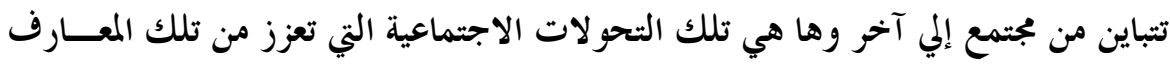

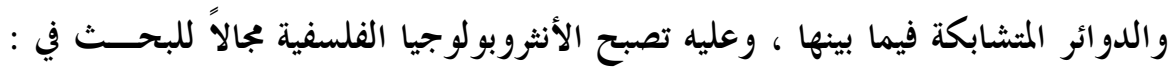

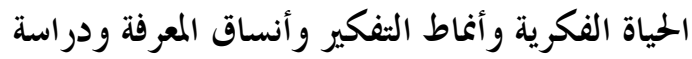

الحقائق الاجتماعية و الأنساق المعرفية العضوية Organic وما فــــوق العضــــية /Super organic

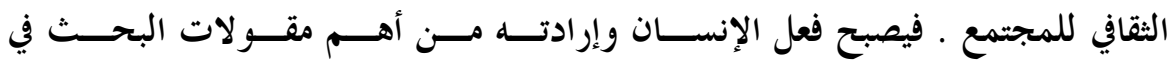

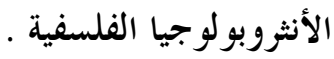

يقول الألماني ماكس شيلر Max Scheler

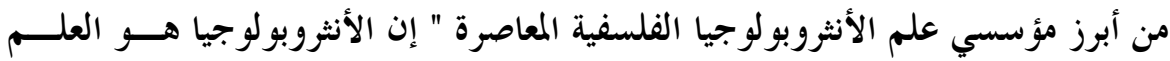

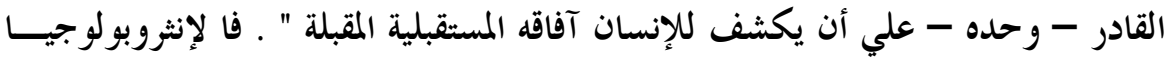

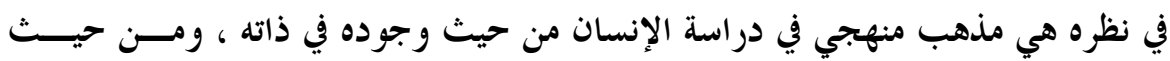

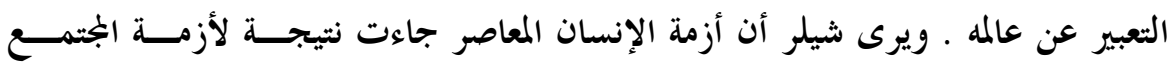
البرجوازي الرأسمالي ، وتقصير الفرد في تقدير أهمية علوم الثقافة ( أي الأنثروبولوجيــا )

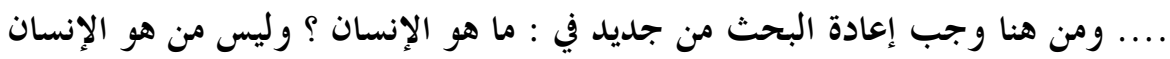

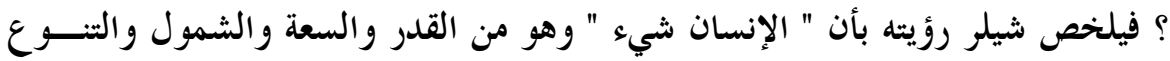


والثفرد بما يعطيه ويمنحه المكانة العالية ، وفي نفس الوقت فإن مهار اته ونشاطاته المعروفـــة

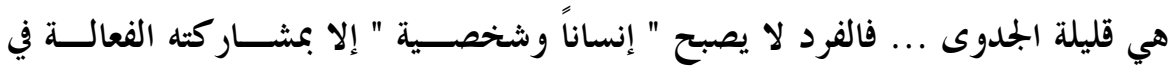

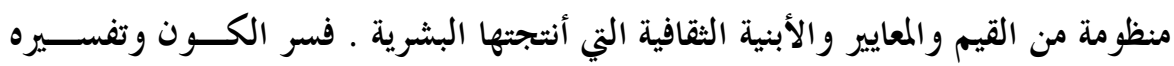

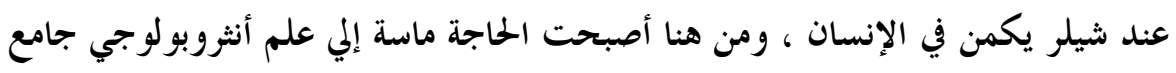
، أطلق عليه شيلر الأنثروبولوجيا الفلسفية .

من المعروف أن تفسير الظواهر الجتمعية Societal ومختلف العلاقات والأحداث

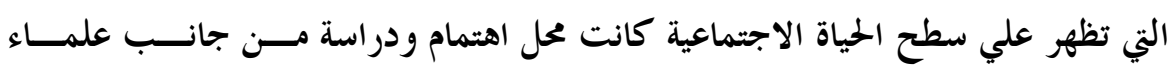

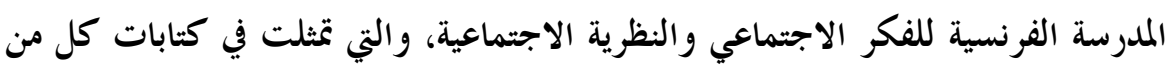

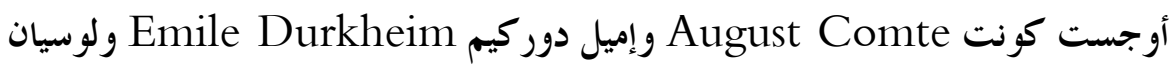

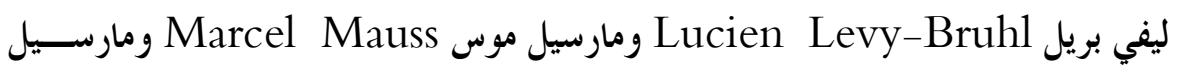

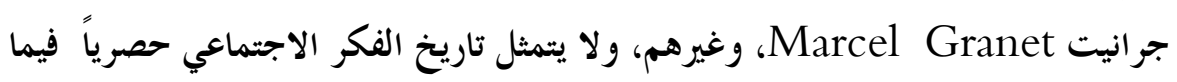

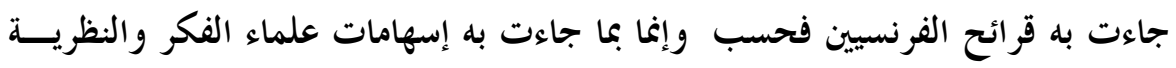

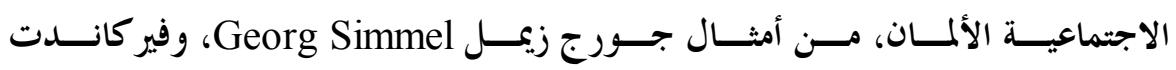

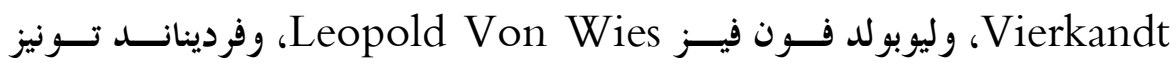

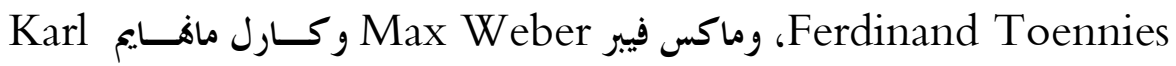
Mannheim

هذا وقد نتج عن خلاصة هذا الفكر الاجتماعي فرعان رئيسيان في مجال المعرفــة

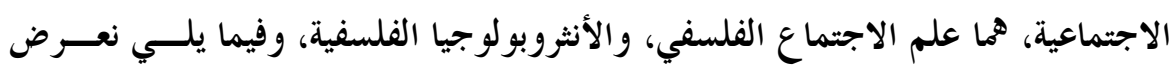

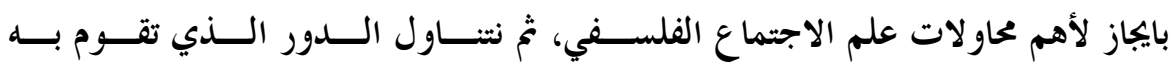
الأنثروبولوجيا الفلسفية وإسهاماتما في دراسة القضايا والمقولات الإنمات الإنسانية العامة.

$$
\text { أولاً : علم الاجتما ع و الرؤية المعرفية: }
$$

يرى جورج زيمل George zemel وأنصار المدرسة الصورية في الفكر الاجتماعي أن البحث عن الشروط القبلية Apriori Conditions للعلاقات

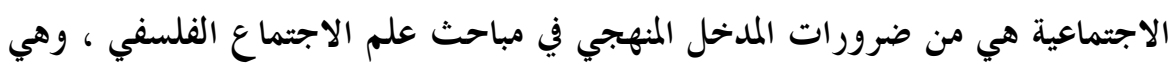


نفس المشكلة التي انشفل بها إيمانويل كانط Kant في محاولته الفلسفية الجادة لاكتشاف

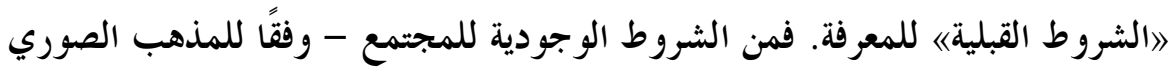

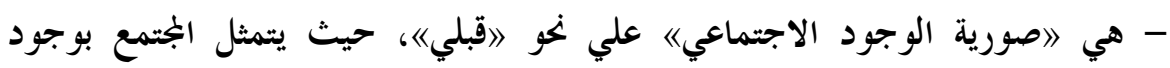

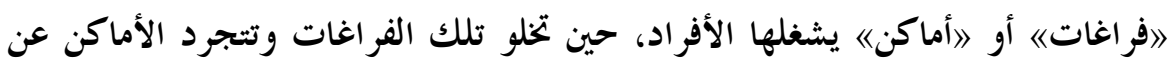

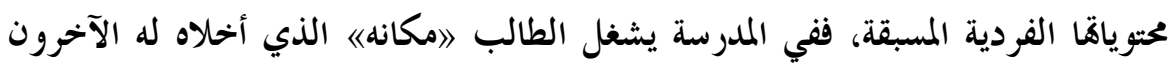

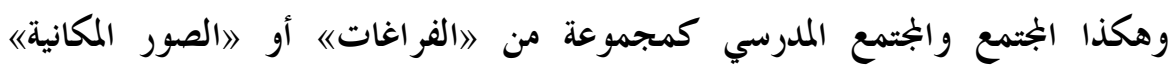
Spatial Forms

ومن ثم نجد علم الاجتماع الفلسفي ينشغل بالبحث عن الأبعاد الفلسفية للعلـــم Philosophical Dimensions of Science

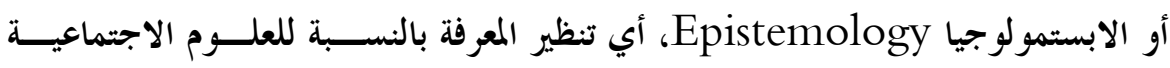

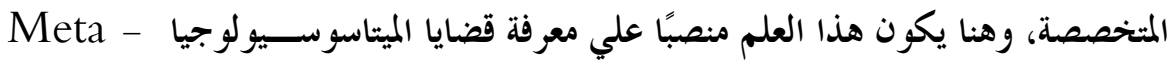
Sociology

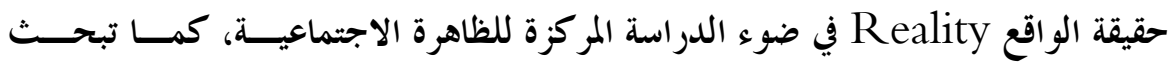

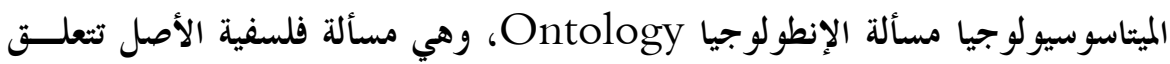

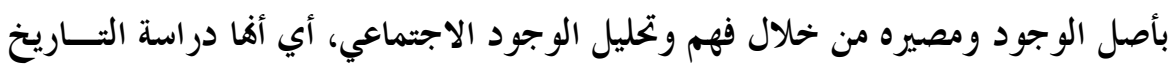
العقلي Intellectual History للوجود الإنساني، وهي الخاولات التي نتج عنها فيما بعد قيام ما يعرف بعلــم اجتمــــاع المعرفـــ The Sociology of Knowledge والذي إنشغل بتجريد الظواهر الاجتماعية عن واقعها الخسوس، ووضع مقولات الاتعل العقل

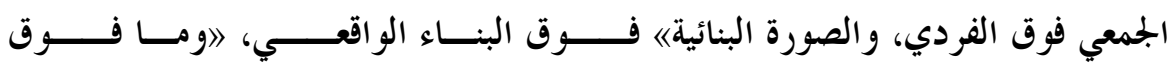

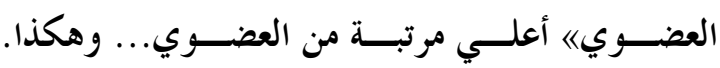

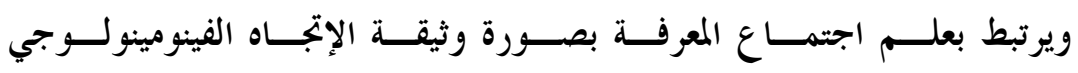
Phenomenology لدي أتباعه من أمثال ياسبرز Jaspers، ومارتن هيدجر Heidegger، وماكس شـــاكر Max Scheler الثيار أو الزّعة الفينومينولوجية إلي دراسة القيم الموضوعية بقصد الكشف عن مكنونــــا 
》الجوهري《 العميق، وذلك من خلال الوصف الدقيق 》المعطيات الوقائع) أثنـــاء تجاربنـــا الجتمعية المباشرة، ولاشك أن عمق البحث في هذا الإتجاه وكثرة تشعبه قد جعلت مفكرًا مشهورًا مثل ماكس شيلر كواحد من رواد التزعة الفينومينولوجية لم يستطع أن يخلع رداء

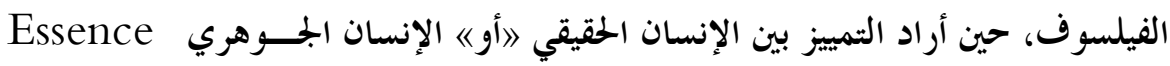

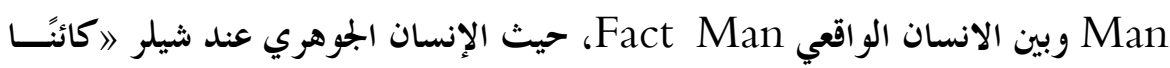

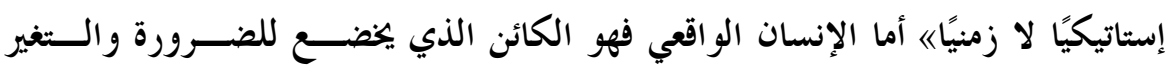

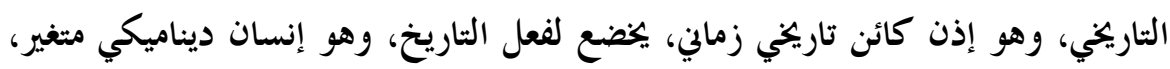
وفق التجربة وحتمية الزمان التاريخي (1).

ثانيًا : الأنثروبولوجيا الفلسفية Philosophical Anthropology تأصلت الأنثروبولوجيا الفلسفية ونشأت خلال العشرينات من القرن العشرين في

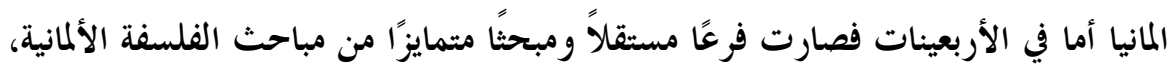

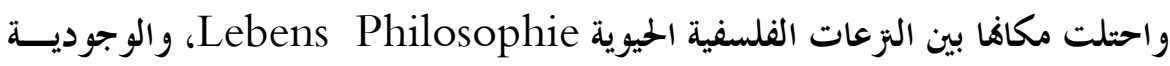
Existentialism كانت غير متماثلة أو متطابقة Not Identical مع تو جهات التزعات السابقة، إلا أها

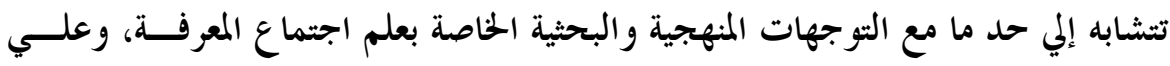

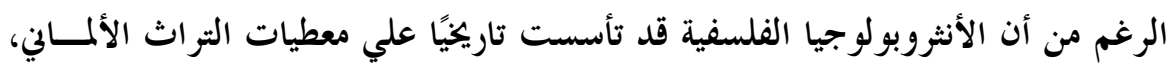

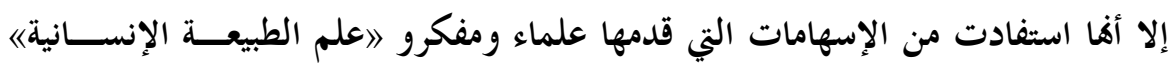
Science of Human Nature الأنثروبولوجيا الفلسفية في نزعتها البحثية والنقدية بين الاتجاهات النقدية التقليدية لعلماء

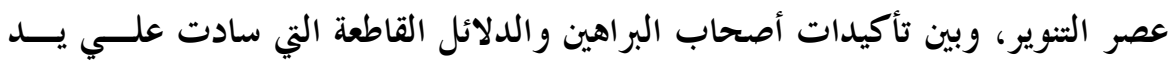

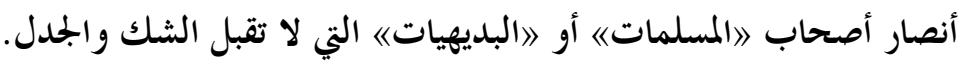

ولقد تأثرت الأنثروبولوجيا الفلسفية في نشأتها الأولي وفي إطار جــل اهتمامهـــا بالبحث عن 》موقع الإنسان في العالمه Man's Place in the World بآراء كــل

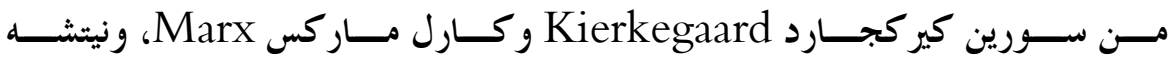


Nietzsche كما كانت هناك تأثيرات لآراء كل مــن باسـكال Pascal، وهيسـدر Herder

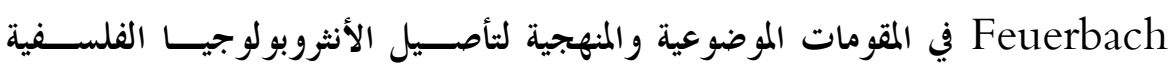

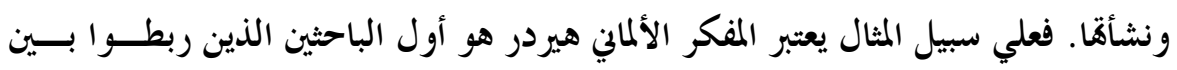

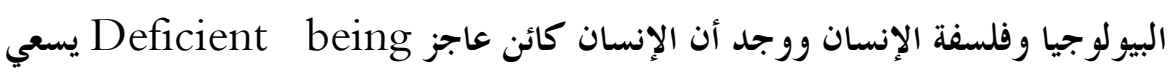

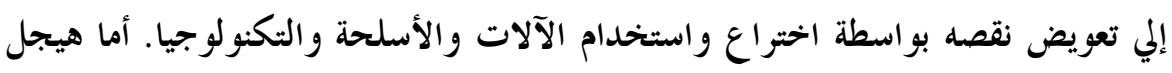

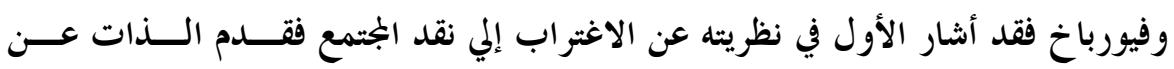

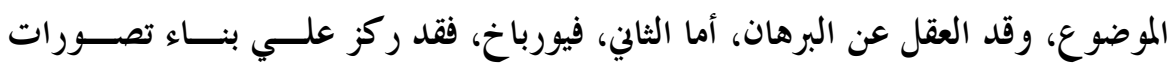

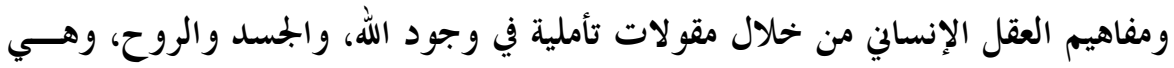

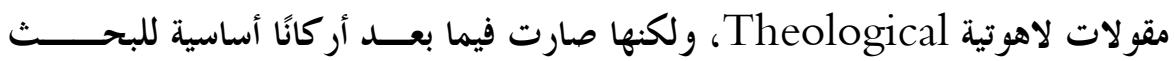
في نظرية الثقافة ضمن مباحث الأنثروبولوجيا الفلسفية(").

وقد ركز موضوع البحث منهجيًا - لدي المدرسة الفكرة الألمانيسة - في مجسـال

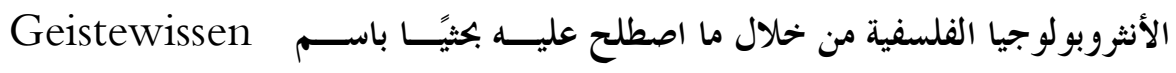

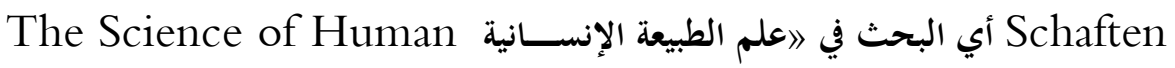

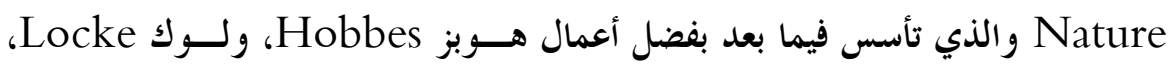

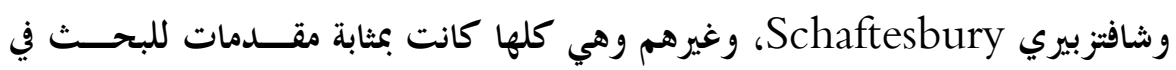

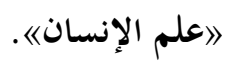

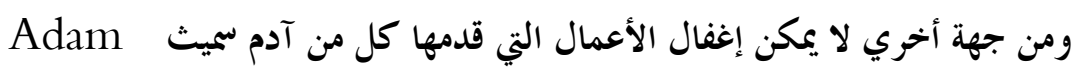

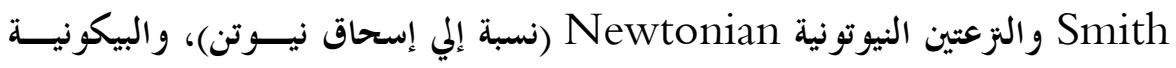
Baconian

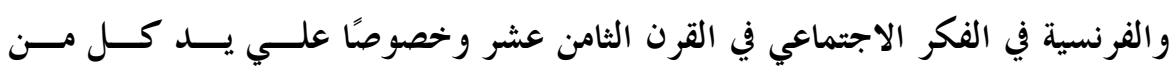

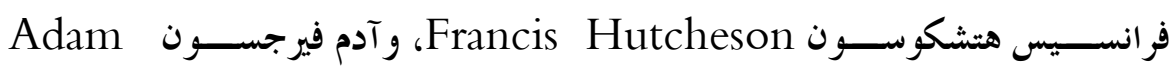

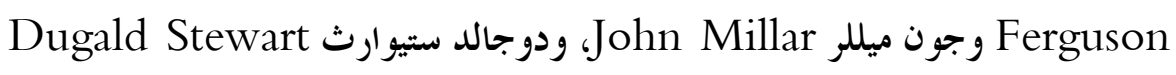

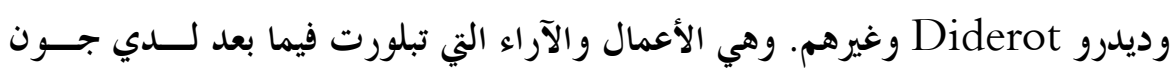

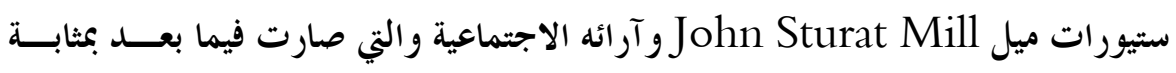


مبادئ هامة في الأنثروبولوجية الفلسفية من خلال آرائه حول الأسس البيولوجية النطبيقية Empirical Biological Basis تضيق الفجوة بين مفهوم الإنسان ووضعه ككائن طبيعي، وبين مفهوم الإنسان في ضــــــاء تأثره بنظامه السوسيو ثقافي.

أما عن اهتمامات الأنثروبولوجيا الفلسفية وموضوعات البحث فيها فتركز علــي

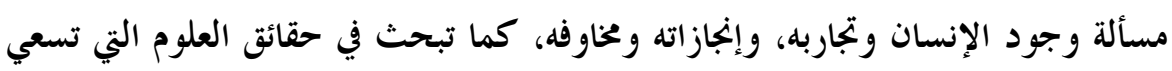

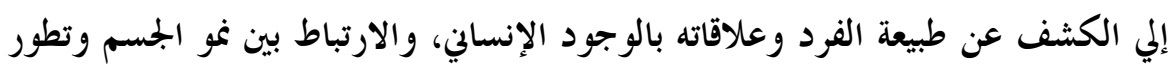

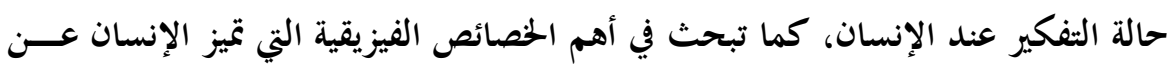

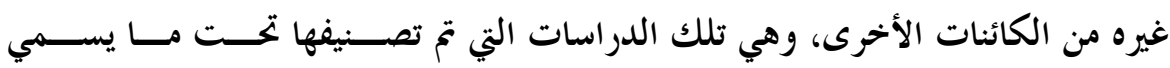

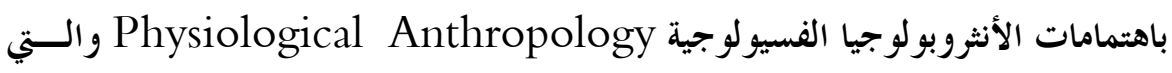
تخنص بالحدود الطبيعية للإنسان ووظائفها وأيضًا الأنثروبولوجيا العلميــة أو الإجرائيسـة Pragmatic Anthropology سواء باعتماده علي الذات أم باعتماده علي آخرين.

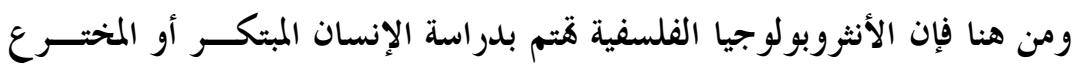

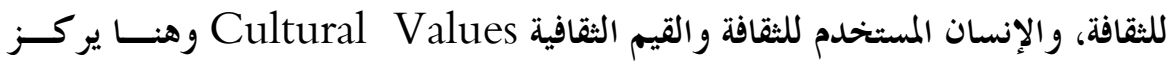

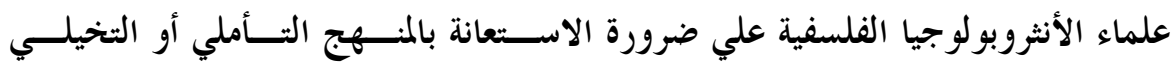

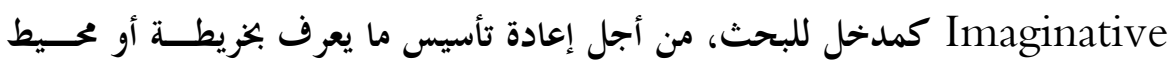
المعرفة Map of Knowledge.

هذا وقد اتسع نطاق ومؤدي البحث في مجالات وموضـــوعات الأنثروبولوجيــا

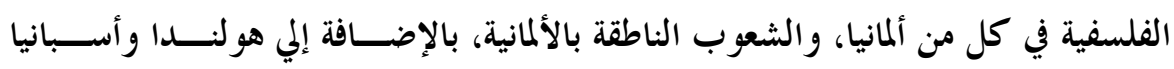

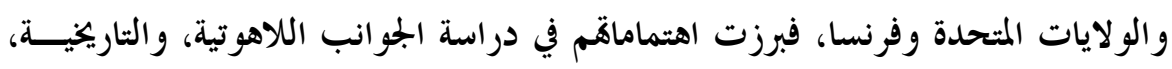

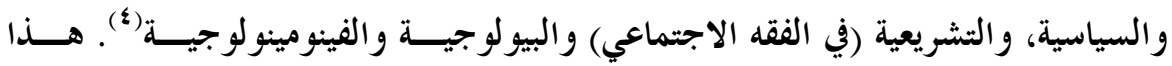

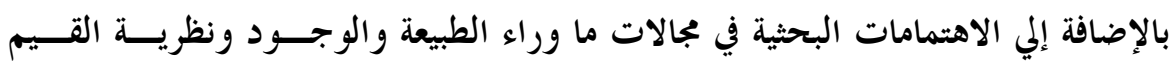
والإبستمولوجيا، وفلسفة العلوم، وفلسفة التاريخ، وقد توجت اهتمامات الأنثروبولوجيا 
Behavioral الفلسفية من جانب العلماء الخســدثين بالبحـــث في العلـــم الســلوكي Science

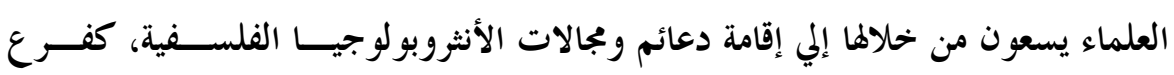
مستقل ومتميز عن بقية العلوم الاجتماعية الأخرى.

ولا شك أن هناك الكثير من علماء الأنثوبولوجيا المعاصرين الذي أسهموا بشكل فعال في تطور الفكر الأنثروبولوجي وجعلها ذات شأن عقليًا وفلسفيًا، وسعت أعمــالفم

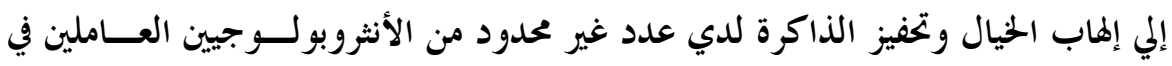

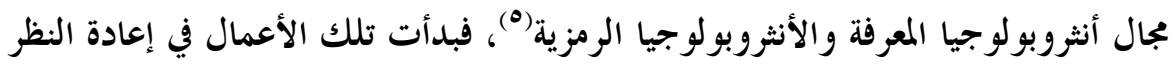

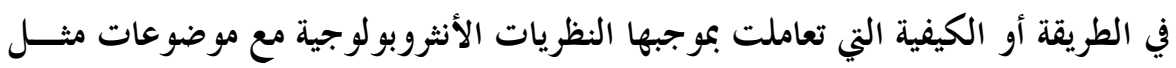

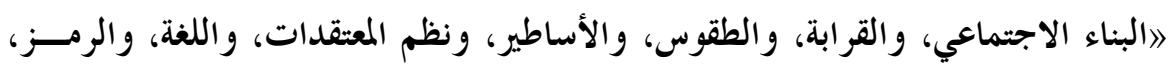
والفن، وغيرها.

وتركز الصفحات التالية من هذا العمل علي الجهود التي قام بها المفكر الفرنسـي

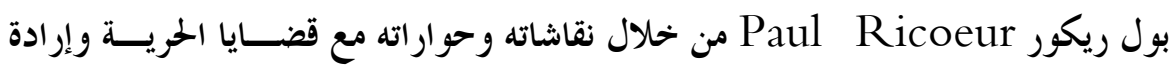

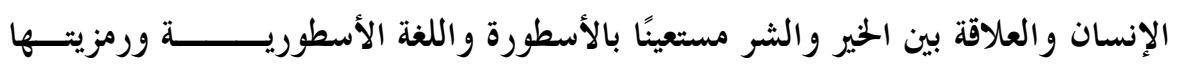
كدالة حية علي ما تحتويه المخيلة البشرية من تراث ثقافئ. - في الحرية وإرادة الإنسان: - مإن

(أيًا كانت المنهجية التي قدمها المفكر الفرنسي بول ريكـــور Paul Ricoeur

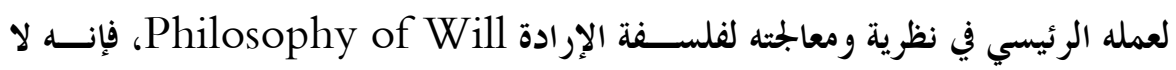

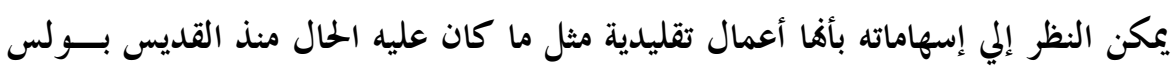
Saint Paul

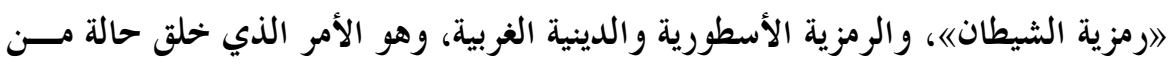

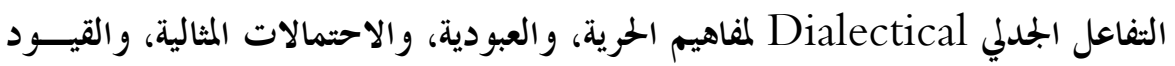

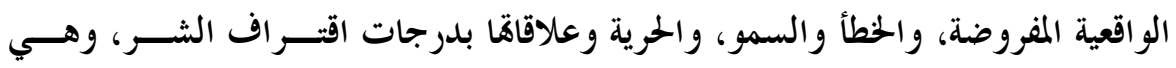

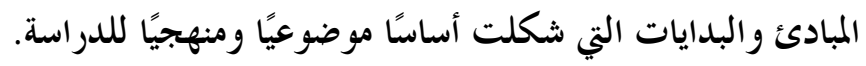


ورغم تقليدية الموضوعات المطروحة وتصدي البعض من المفكرين لدراستها إلا أن

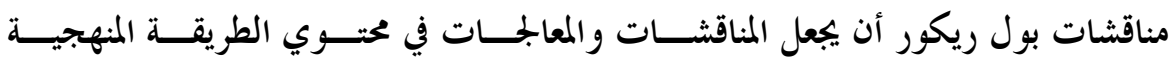
Methodological

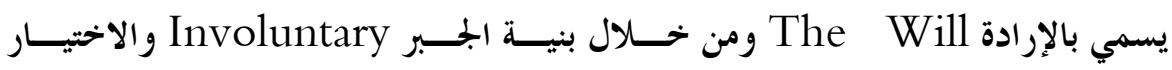
Voluntary

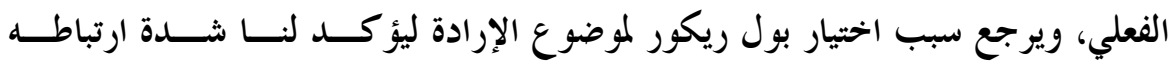
بموضوعات مذهب الفينومينولوجيا Phenomenology الفرنسية. ومن المعروف أن أدموند هوسرل Edmund Husserl الفيلسوف الألماني هو

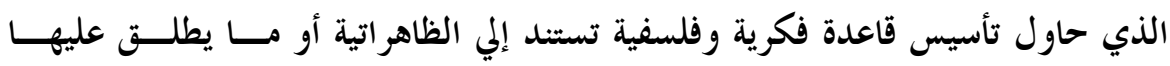

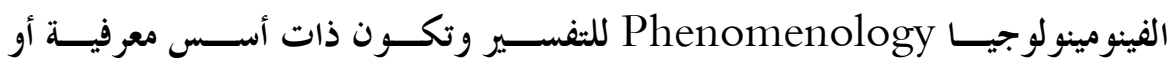

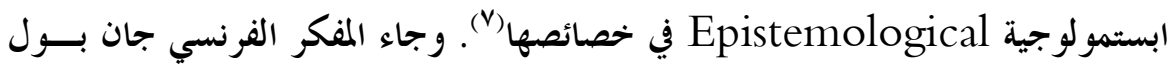

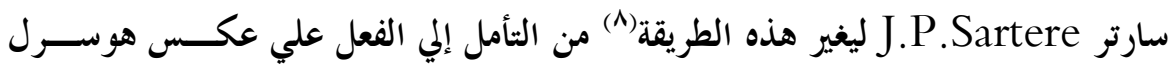

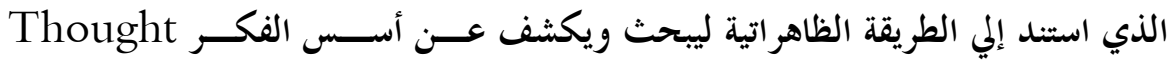

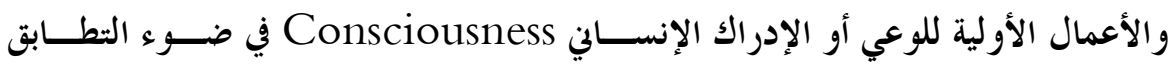

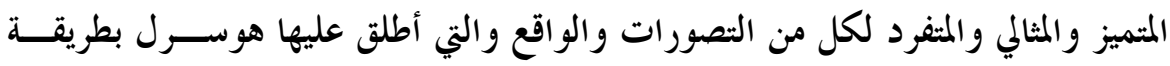
مبحث ذاتية الجوهر للموضوعات Eidetic Method وهي الطريقة التي حاول مارتن

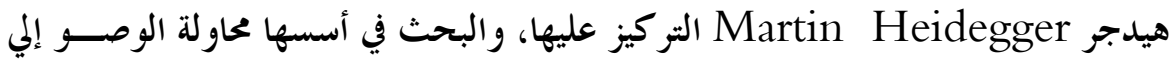

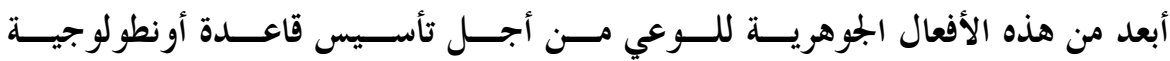
Oتfological 》سارتر هذا التمايز الأساسي الذي قدمه 》هيدجره بين الأفعال الشعورية والانغماس في البنيوية أو الجوهر Being، والتي أشار إليها هيدجر بأها أفعال محتملة ومككنة.

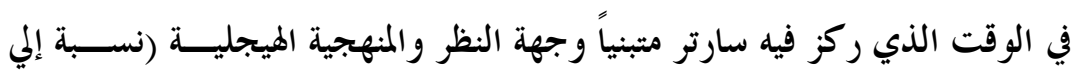

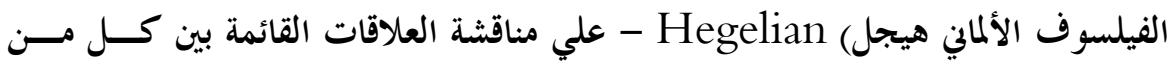

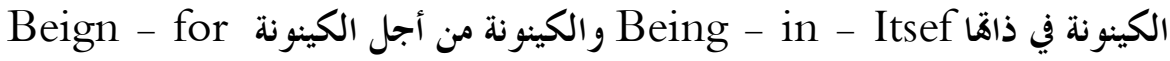
Itself 
الفصل بين الكينونة Being التي في ذاها In - Itself واللاشــيئية Nothingness التي هي من مصادر الوعي والإدر الك الإنساني.

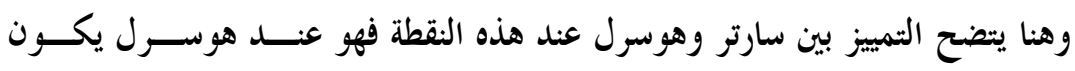

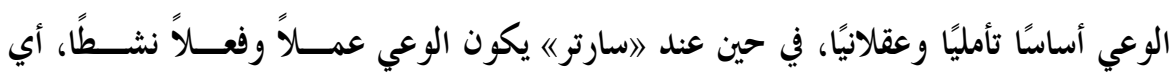

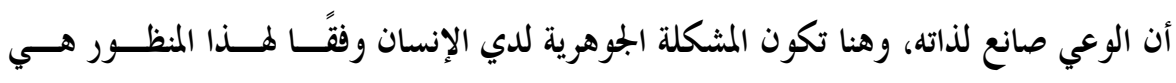

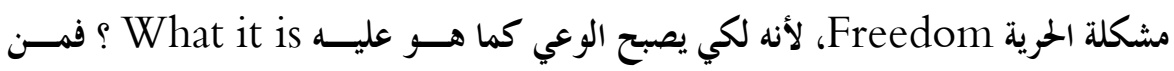

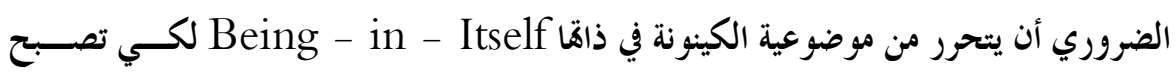

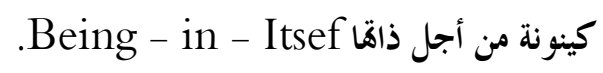

وبالثركيز علي مشكلة إرادة الإنسان فقد جعل بول ريكور الحرية الإنسانية هـي

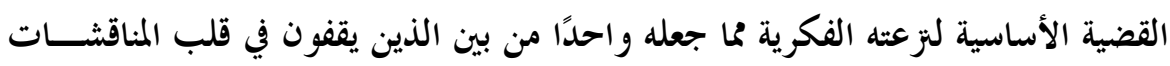

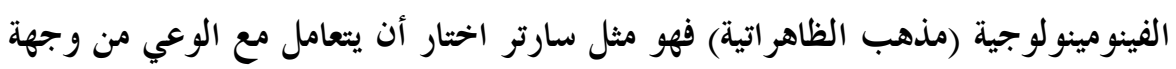

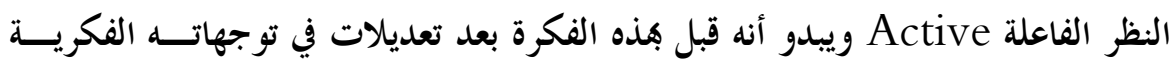
لاسيما وأن المبحث الرئيسي لدي ريكور ينصب علي مشكلة الإرادة الإنسـانية والــتي تفهم الحرية في محتوي الطبيعة لا في رفضها. من جهة أخري فقد اختار بول ريكور في دراسته عن الإرادة أن يسير وفقًا لما جاء بلهاء

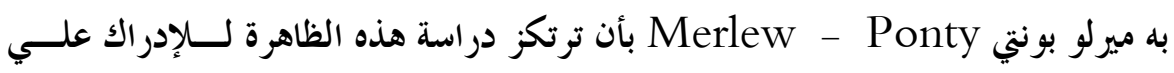

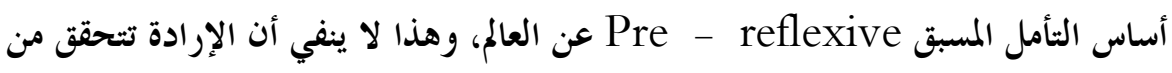

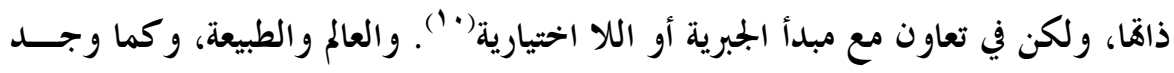

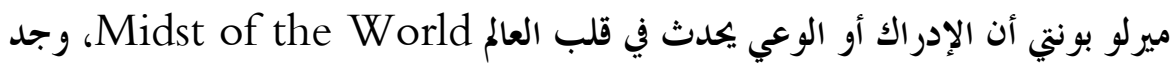
بول ريكور ن الحرية في قلب الطبيعة، وهي التي تمثل التأملات الأولية أو القبلية لظاهر اتية التية العالم أو الجسم أو حتي الللا إرادية أو الجبرية.

وقد علق بيير تيفيناز Pierre Thevenaz. في كتابه بعنسوان مــا المقصــود

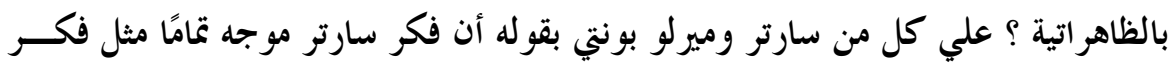

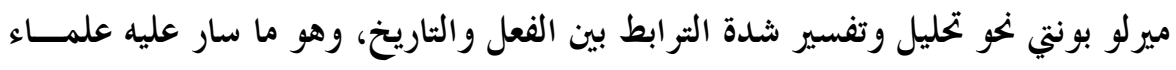


المدرسة الفرنسية (أنصار المذهب الظاهراتي) الذين ارتموا بشدة في أحضان التاريخ. وهنـــا

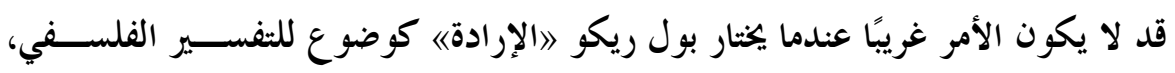

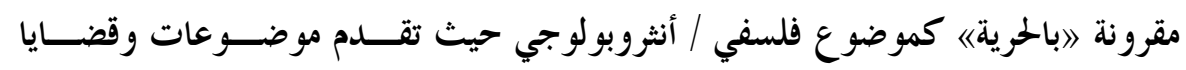

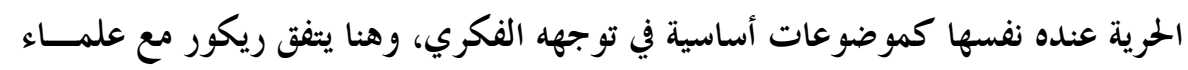
الأنثروبولوجيا بأن محتوي هذا الموضوع هو النظرة الشمولية والكونية Global للإنسان وأن هذا الموضوع ينال أهمية خاصة من خلال منهجية مبحث الجوهر أو التفــرد الـــذاتي Eidetic

ومركزية قضية الحرية في فلسفة ريكور للإرادة تفترض ثلاثة أسس للتفسير هي:

$$
\text { 1 - الحرية والطبيعة. }
$$

r - ب الحرية و القابلية للخطأ.

$$
\text { r- الحرية والحطأ. }
$$

فتر كيز الإنسان علي مشكلة الحرية ليس عملاً ترفيًا أو مختزلاً، لاسيما وأن مبـــأ ريكور عن الحرية هو علي النقيض من سلبية وإنكار ورفض سارتر لها، ولهذا فهي في مبدأ

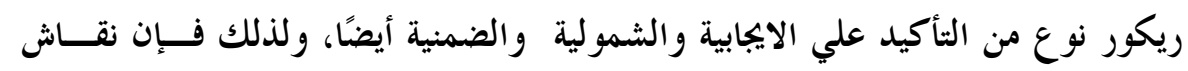

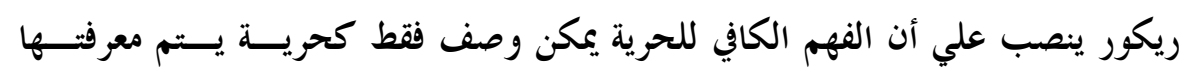

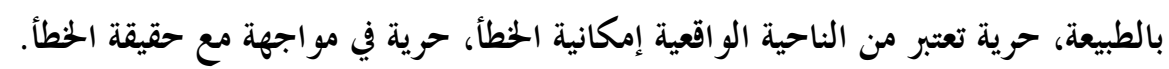
ويتضح مما سبق أن الختوي الكلي لهذه المناقشات يكمن في أن الحرية هـــ مـــادة

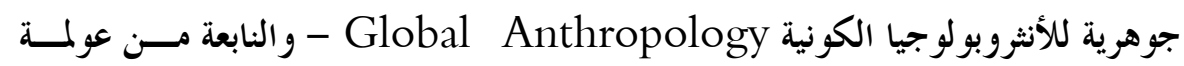

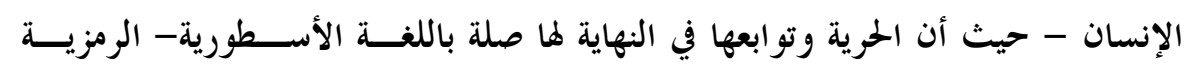
Mythic - Symbolic Language

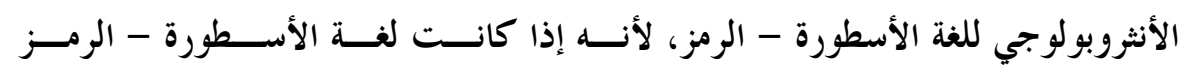

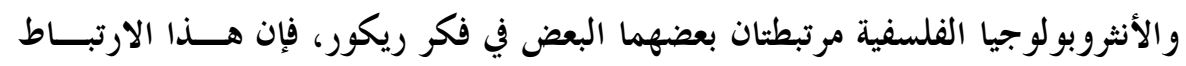

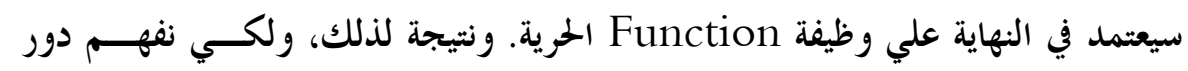


Role الحرية وحدودها في علاقتها بالرموز والأساطير، فمـن الضـــروري أن نتصــور

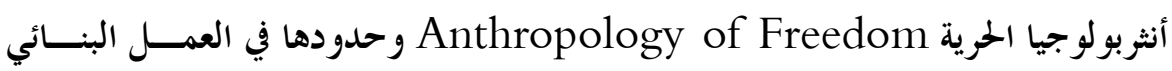
الكلي أو العمل الاستدلالي Constructive عند بولية ريكور.

Freedom and Nature أولاً : الحرية والطبيعة

من المعروف أن مبدأ ريكور للحرية تم تصوره وتطوره في ضوء محتسوي أو عمــل

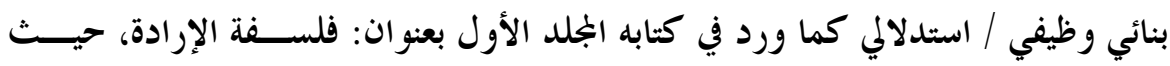

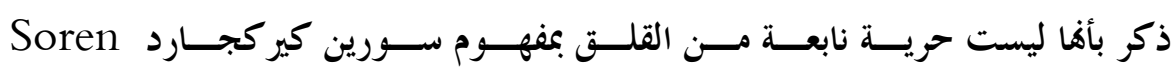

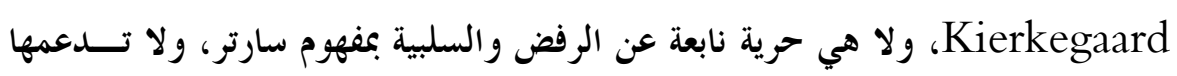

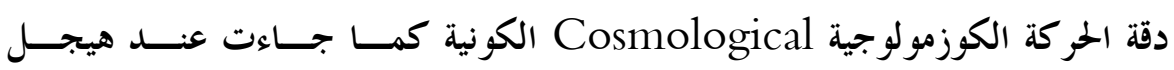

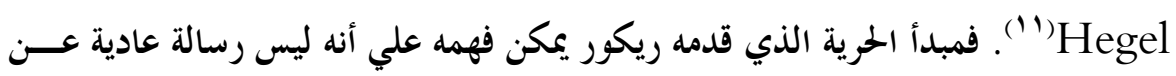

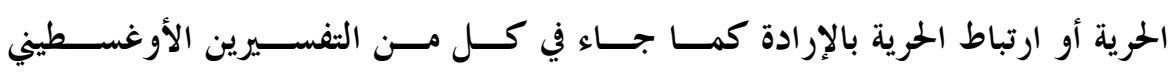
Augustinian

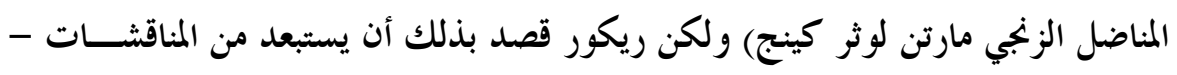

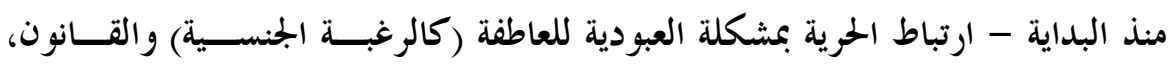

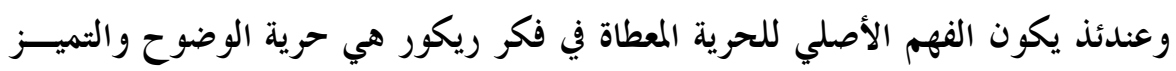

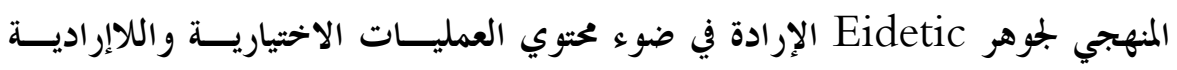

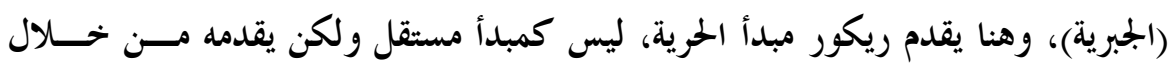

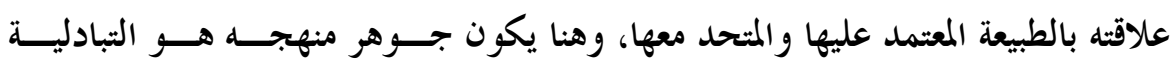

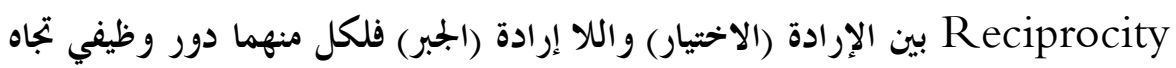

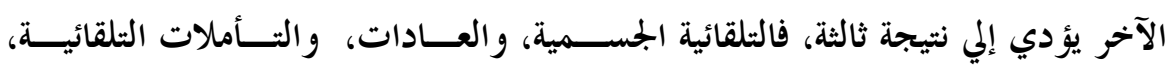

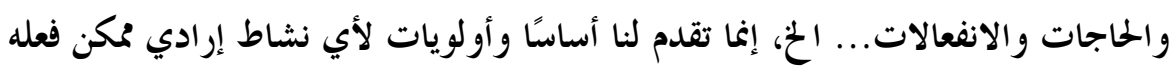

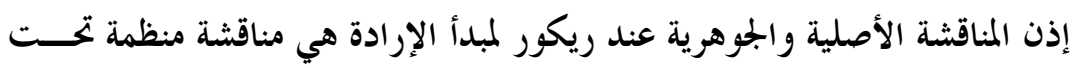

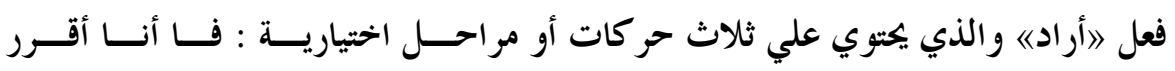


IIdecide

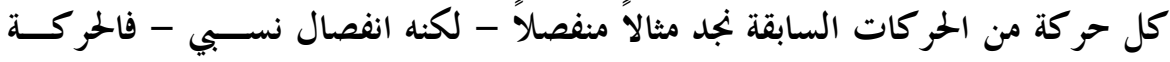

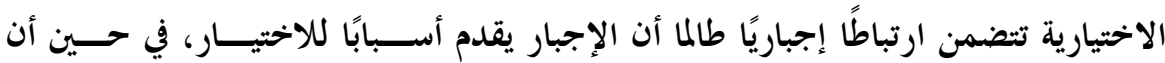

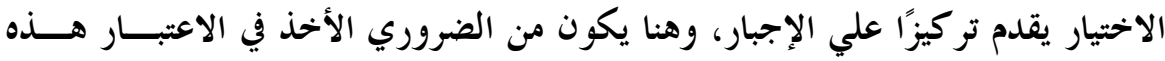

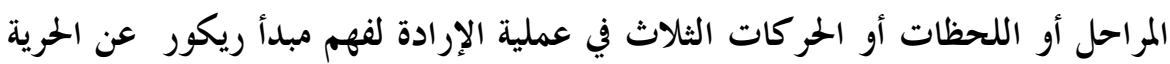

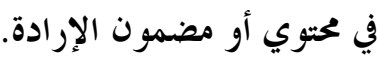

وفيما يلي نضع بين يدي القارئ النص التالي كما جاء في كتاب ديفيد راسموسـين

David M. Rasmussen في بوسطن بعنوان : اللغة الأسطورية - الرمزية والأنثروبولو جيا الفلسفية ـ والذي يشسير إلي خلاصة رؤية ريكور للإرادة والحرية، والنص كما نعرضه دون تربمة منا هو :

The Central theme of Ricoeur's thought. From the point of view of his attempt to constract a philosophical Anthropoloy, is Freedom and its Limitations. Although Ricoeur originally considered freedom in relationship to nature, Later he turned to Myth and Symbol as Phenomena Constitutive for the experience of freedom and its limitation.

ومن خلال المناقشات الحاصة بالحرية والطبيعة والإرادة تتضح لنا بعض النقاط التالية :

$$
\text { أ الحرية واتخاذ القرار Freedom and Decision }
$$

يشير تحليل وتفسير الإرادة تحت أي ظرف إلي حالة اتخاذ القرار الذي يدل علــي

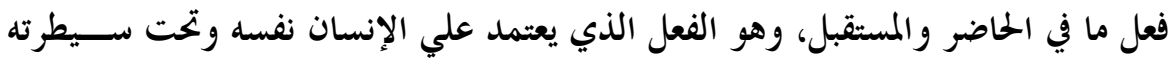

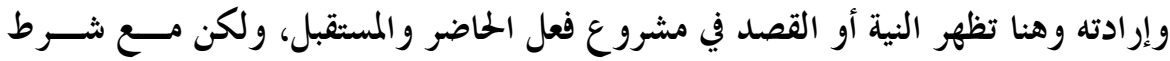

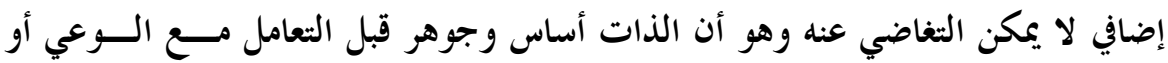

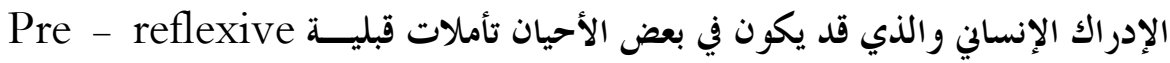

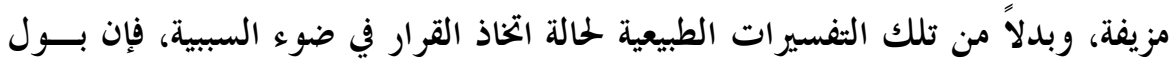

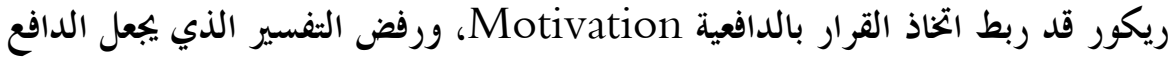

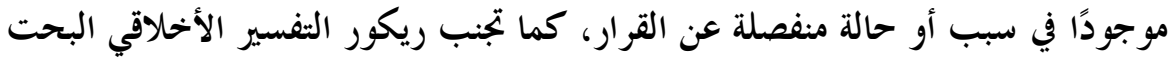


للدافعية، والذي قد يربط عملية الخاذ القرار بمخطط أو مخططات تفسيرية قد تخفي حالـــة

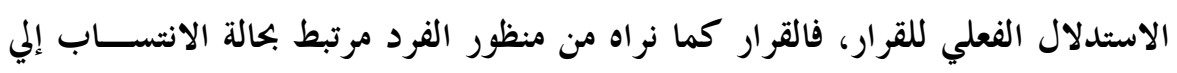
الذات Self - Imputation والدافعية في ضوء النشاط التبادلي بين القيود الجوهريسـة فئس للحرية وإرادة الإنسان، وأن كل منهما لا ينفصل عن الآخر.

وهنا تكون الجبرية Involuntary من أجل الإرادة، والإرادة موجودة بسـبب

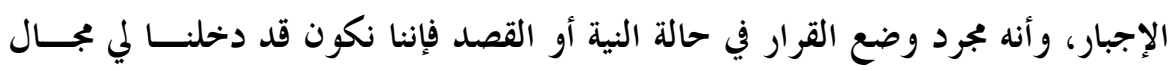

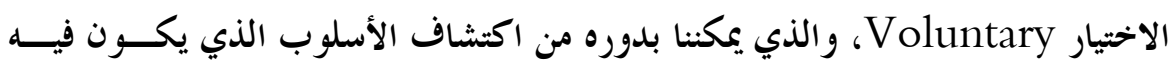

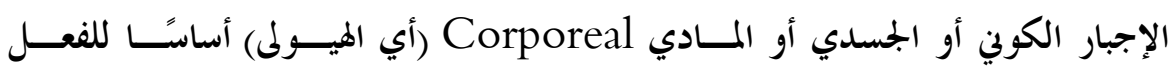

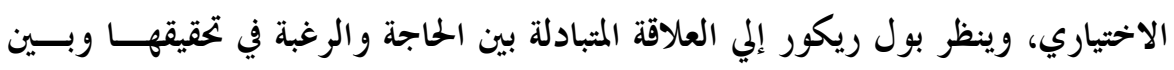

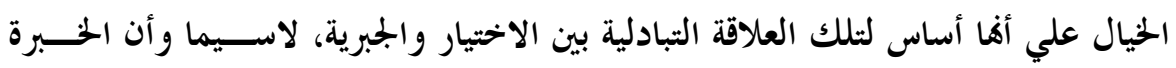

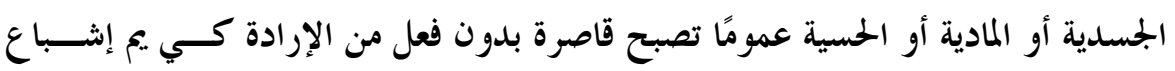

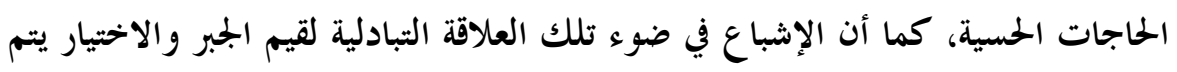

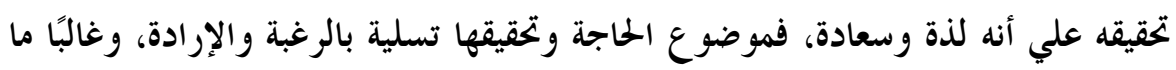

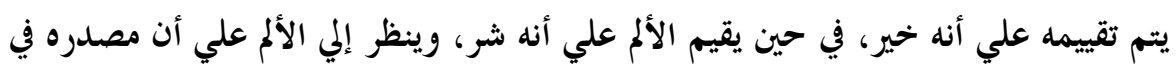
الحخوف وليس في الحاجة.

ولا شك أن بول ريكور بنظرته السابقة يحاول أن يوسع مــن طريقتـهـ المنهجيــة

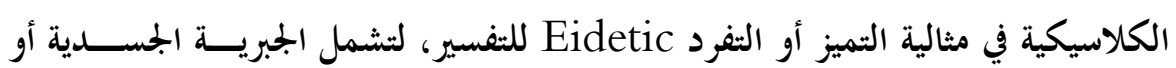

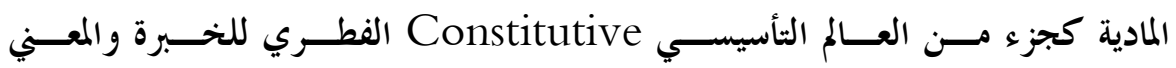
.Meaning

فالتعريف المبدئي للحرية هي ليست الحرية التي تم تكوينها وتأسيسها باعتبــارات

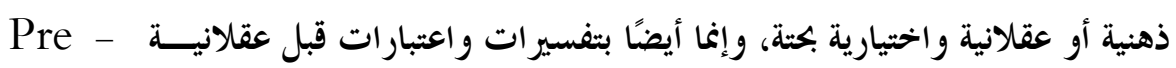

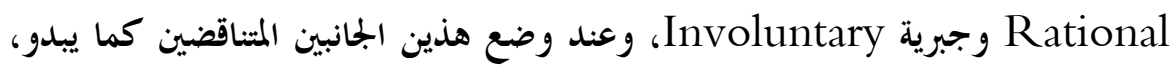

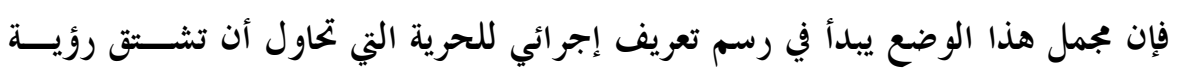

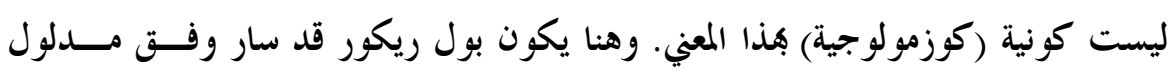


هوسرل فيما يتعلق بإعادة التقييم الفينومينولوجي للثنائية التقليدية بين الحريــة العقليــة

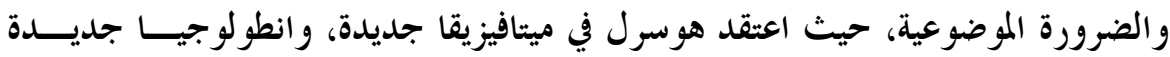

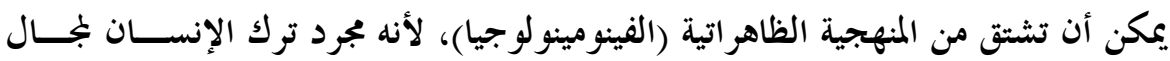

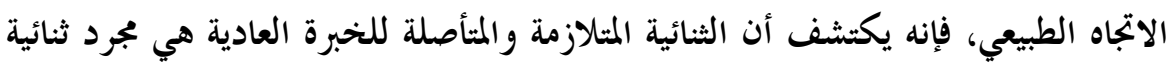
مزيفة.

ورغم أن مبدأ الحرية حتى الآن عبارة عن رسم تخطيطي Sketchy، إلا أنه مــن

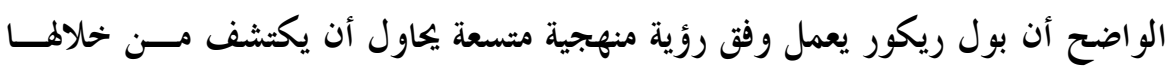

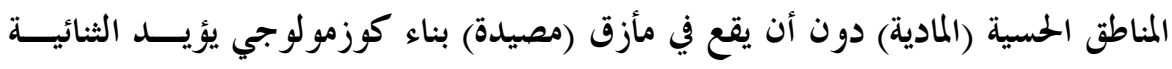
وعليه فإن تصور اللحظة الأولي لفعل الإرادة، هو فعل القرار، وهنا يتم تقديم مبدأ الحرية لتكون نقيضًا للتعريف الكوزمولوجي للحرية.

\section{Freedom and Action الحرية و الفعل}

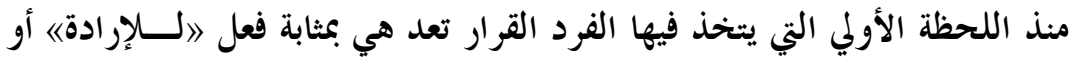

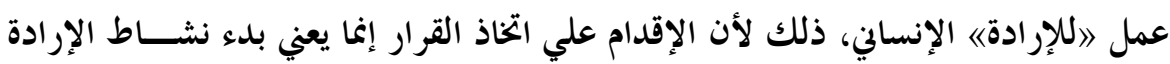

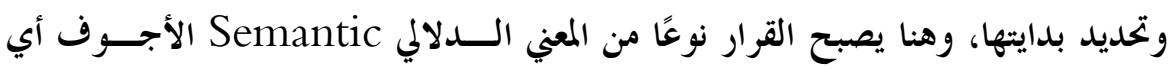

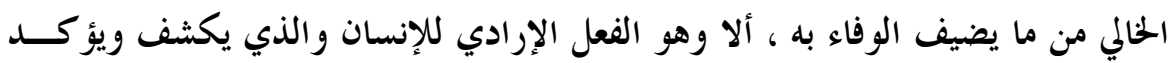

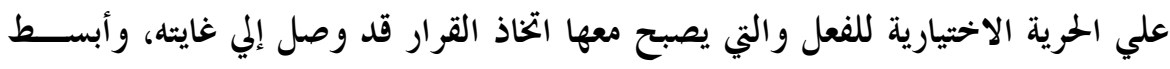

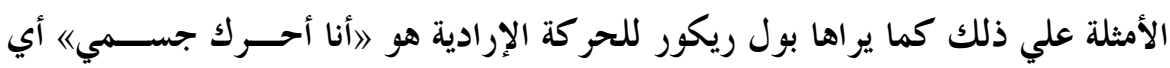

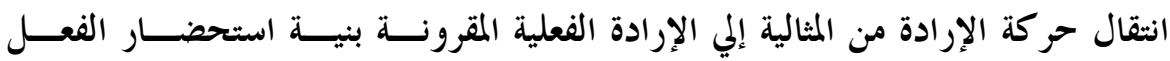
Presence of Action الطريقة التي يربط فيها الفرد ذاته بالأشياء. وقد أدت تصورات الفعل في علاقاته بالأشياء - عند بول ريكــــور - إلي القـــــل

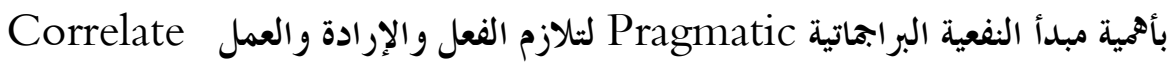
ففي المثال السابق لا يكون الجسم هو موضوع الفعل بل هو وسيلة أو أداة doing 
الفعل Organ أي أن الجسم يكون متضمنًا ومستغرقًا في عمليتي اتخـــــاذ القرار وفعل الإرادة حتى تستكمل العمليتان ويمكن إتمامها.

ومن هذا المنطلق نجد اهتمامًا من جانب العلماء في إبراز العلاقة بين كل من الفكر

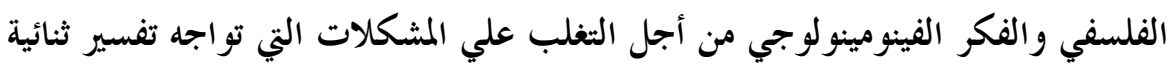

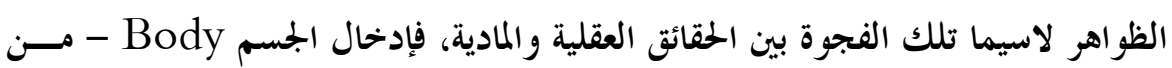

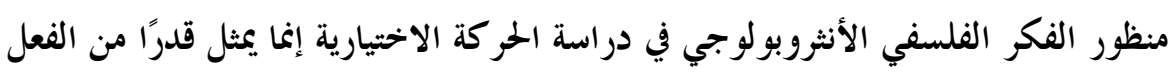

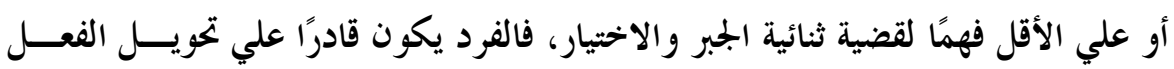

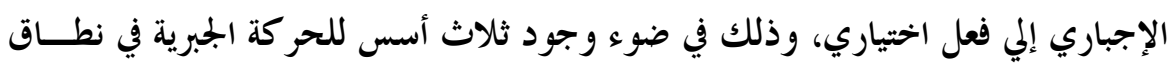

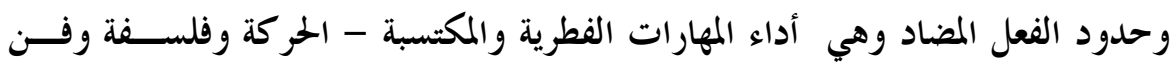
أدائها- العادة أو روتينية وتلقائية الأفعال.

فأداء المهارات يرتبط بشدة بالمبدأ العلمي الموضوعي وهو انعكاس لما نملكــهـ مـــن

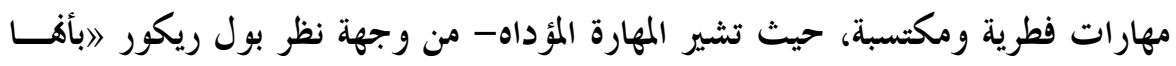

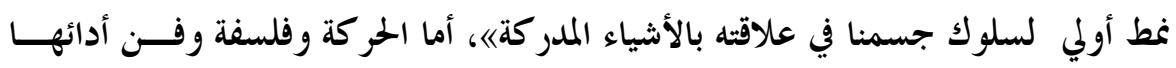

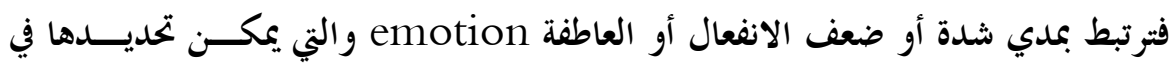

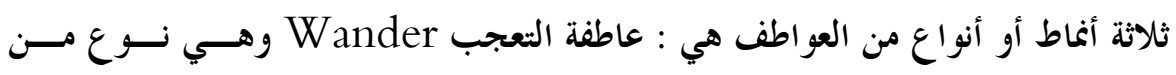

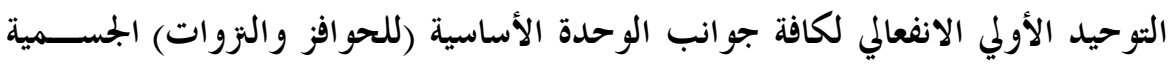

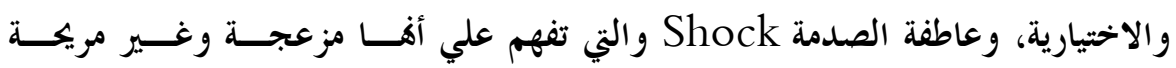

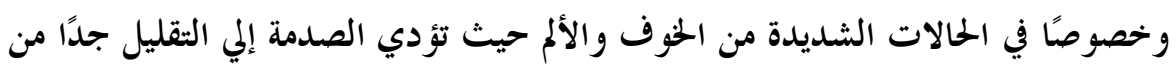

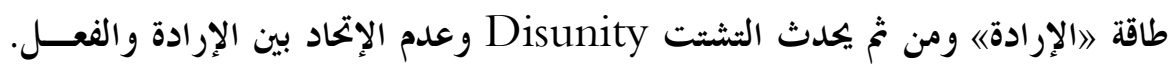
فانفعالات الصدمة تؤدي إلي ضعف 》الاختياره بينما انفعالات التعجب في أقصي شـكـل

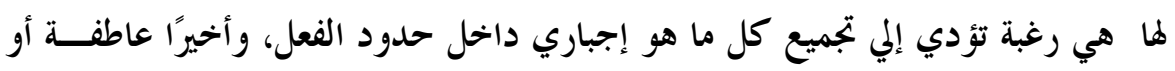

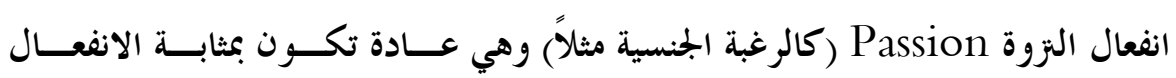

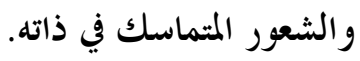


أما العادة Habit فتشير إلي الجمال الثالث للتلقائية الجسلدية، والــتي بمقتضــاها

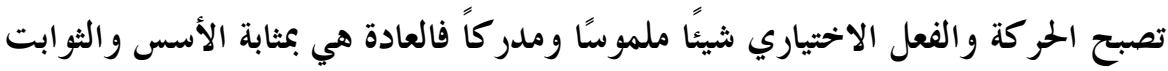

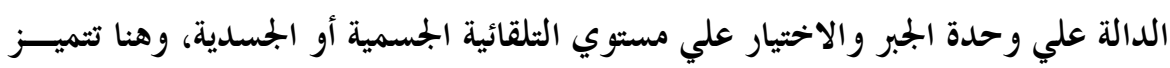

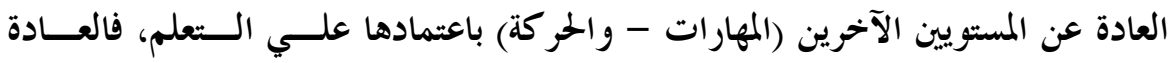

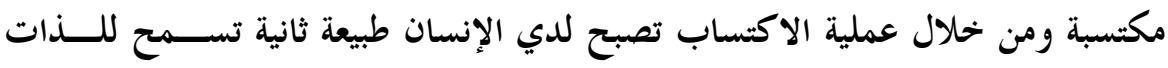

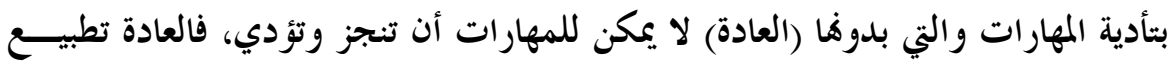

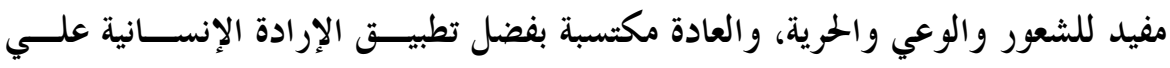

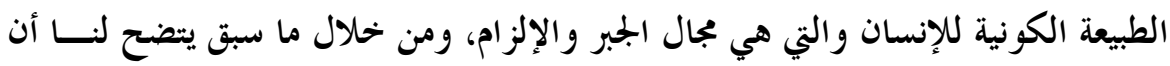

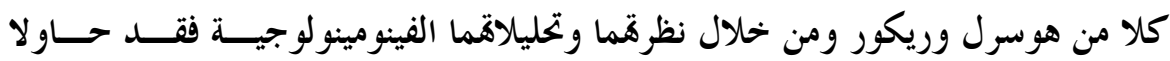

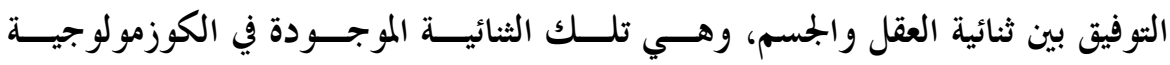
الكاسيكية.

Freedom and Consent ب- الحرية والقبول

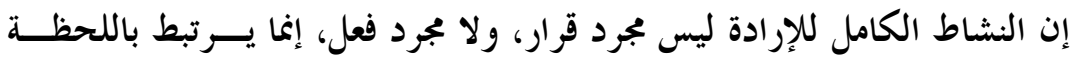

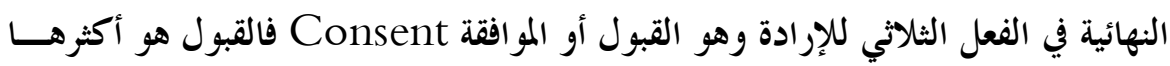

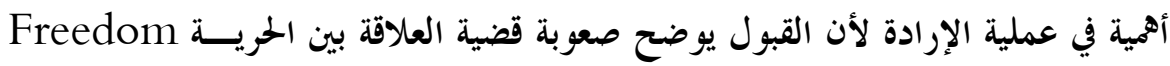

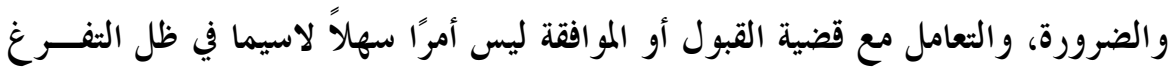

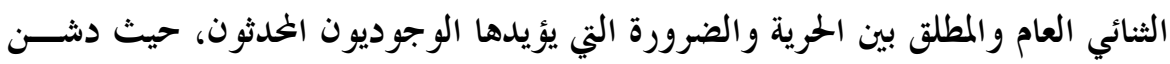

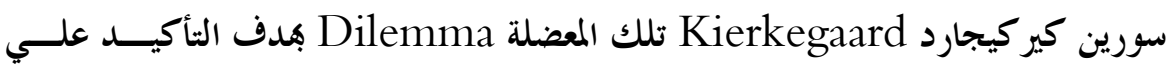

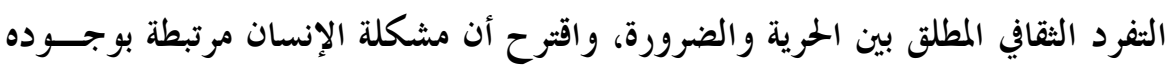

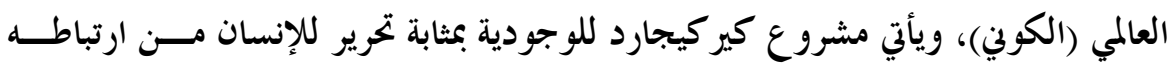
بالعالم (الكولن) لكي يتأكد من إمكانات وجوده الخاص. ويظل الأمر، ويبقي علي جــان بول سارتر Sartre أن يعيد تأكيد هذا الثقاق الراديكــالي (الأصــــلي) بــين الحريسـة

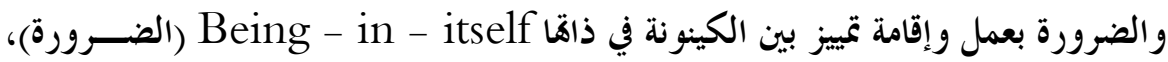

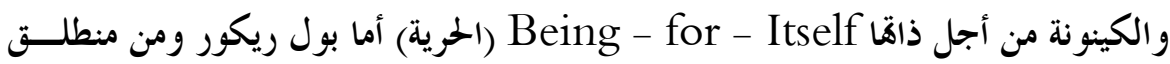




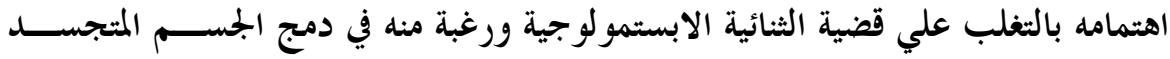
Marcel

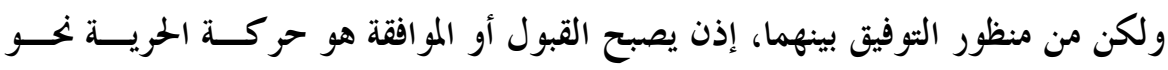
الطبيعة لكي تصبح متحدة مع ضرورةقا وتمويلها في ذاتما. لكن الأمر ليس بهذه السهولة - كما يبدو فالقرار النهائي للحرية والضـــرورة في

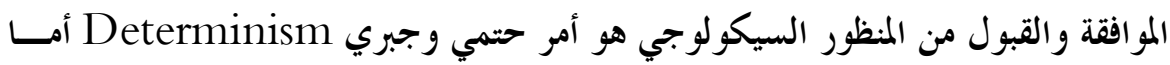

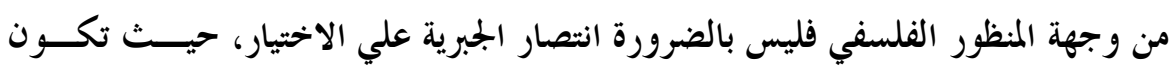

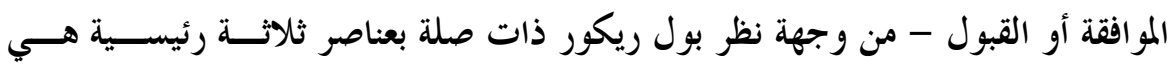

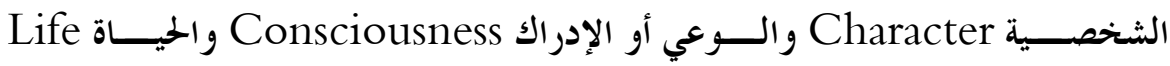
فالشخصية يتم تعريفها علي أفها الأقرب للإرادة، فهي التي تقيد الإنسان باتخاذ كل قـــــار

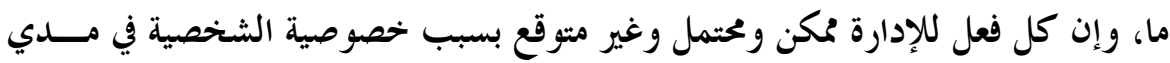

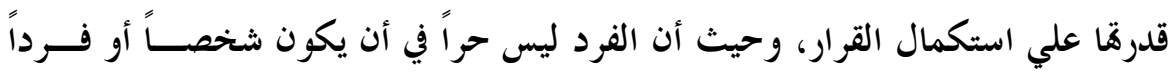

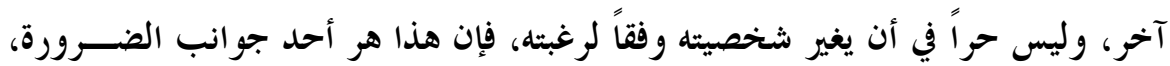

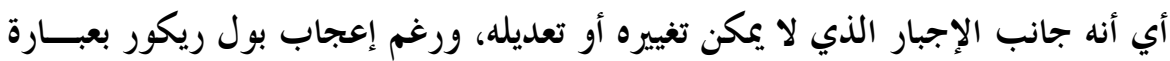

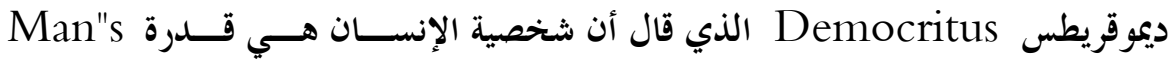
Character is his fate للشخصية لأن الشخصية هي موضع حرية الإنسان(\&) (1) .

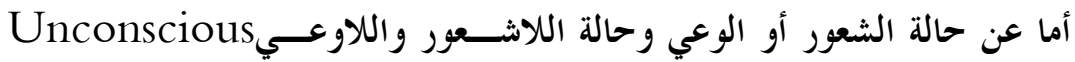

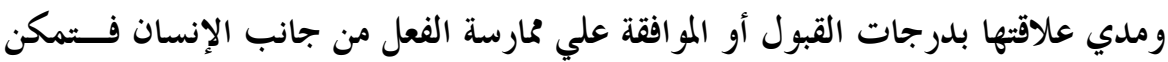

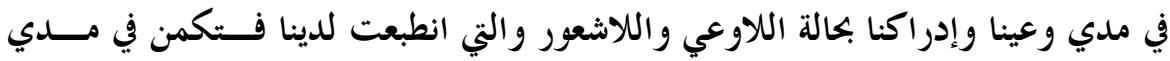

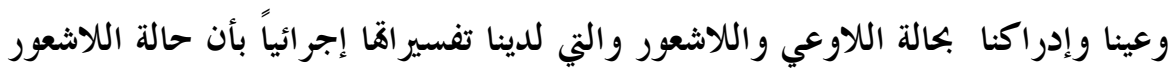
هي تلك التي لا نشعر بها، بل وصل الأمر بالبعض إلي تفسير ما نملكه من شعور بأنه بجرد

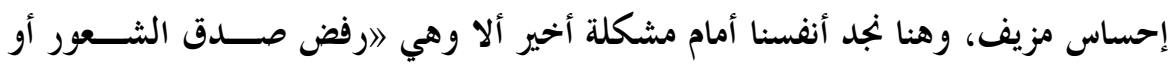

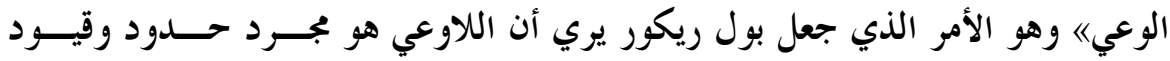

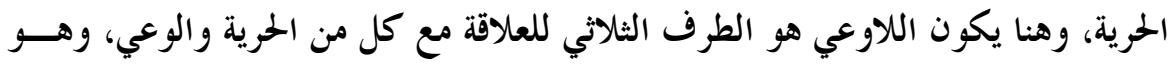


الأمر الذي جعل بول ريكور يوجه انتقاداته لتفسيرات سيجموند فرويســـ في الجوانسب

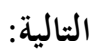

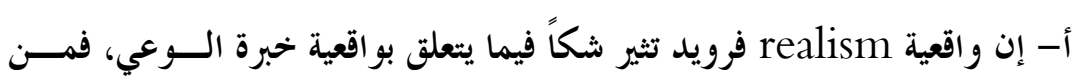

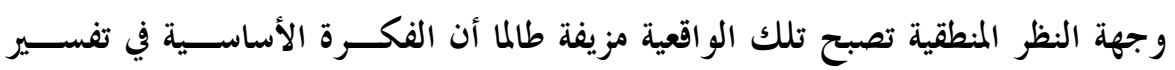
اللاوعي تؤكد حالة الوعي، حيث يجب علي الفرد أن يكون علي وعي (شعور) بالخاصية

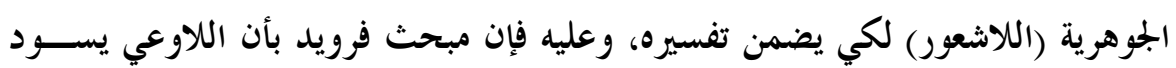
علي الوعي إنما هو أمر يثير التساؤلات.

ب - يرتبط هذه الو اقعية Realism السبية Casulism أو العليسة ميسل إلي

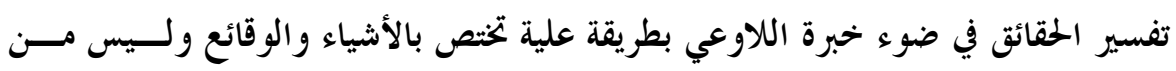

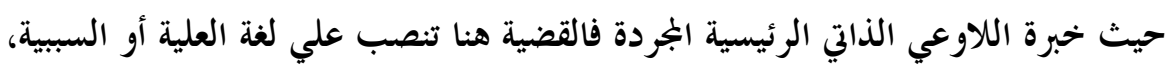

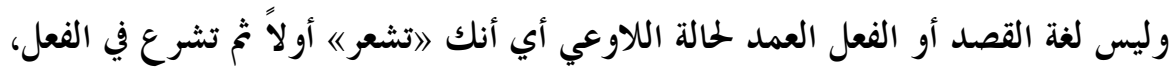

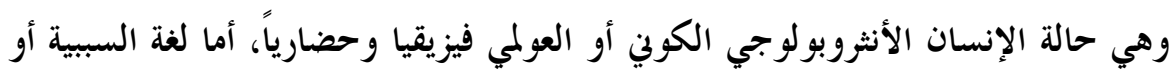

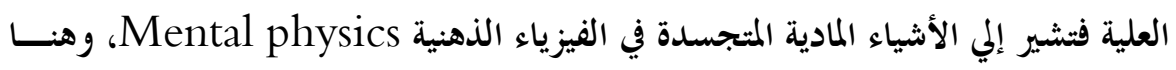

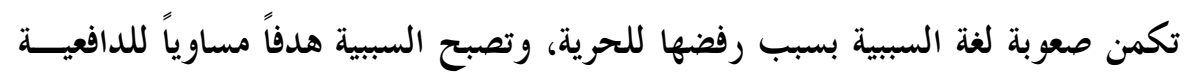

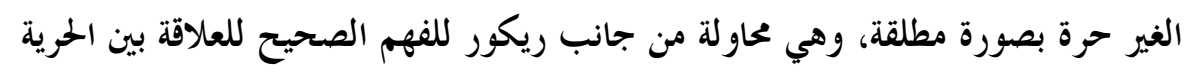
والطبيعة.

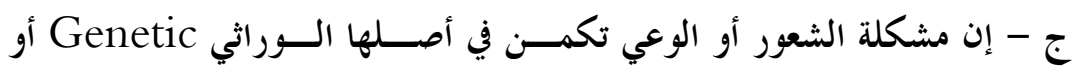
النشوئي التطوري، أما اللاوعي فقد اكتشفه وأكد عليه فرويد رغم علمه بالمبادئ الوراثية

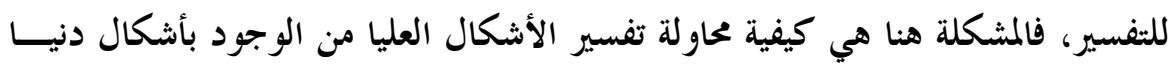

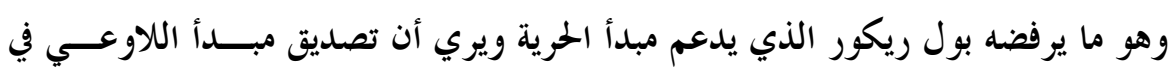

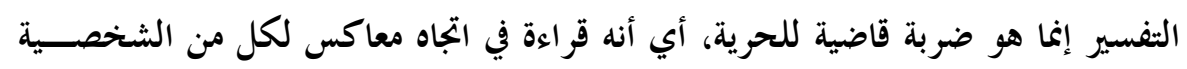

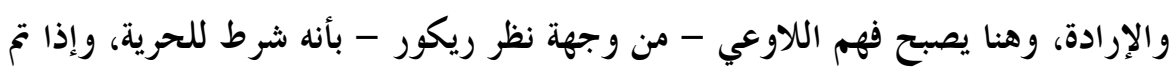

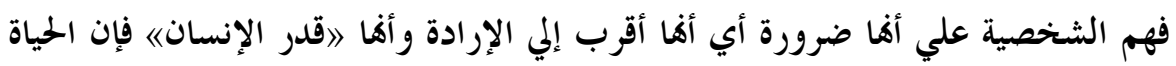
هي التي تلي الشخصية ثم اللاشعور أو اللاوعي (10). 
ويمكن تحليل الحياة Life من خلال ثلاث مراحل أساسية هي:

- البناء الفيزيقي، وهي المكونات البيولوجية ووظائفها والتي غالباً تحد من حريسـة الإنسان، حتى وإن كانت هذه الوظائف ليست محكومة بواسطة الحرية، فالجهاز العصـبي،

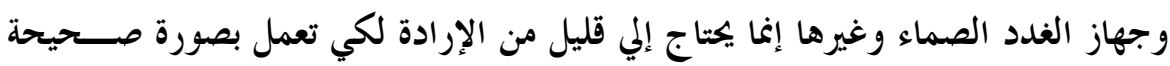

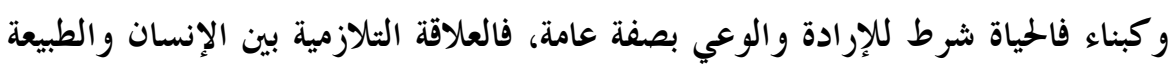

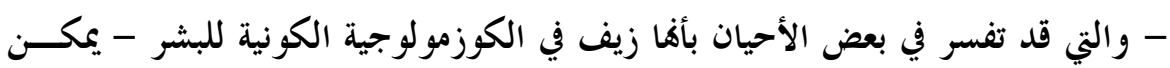
تفسيرها وحلها بواسطة دور الإنسان الفرد.

- النمو الفيزيقي، وهو البحال الثاني الذي تتعرض فيه قضـــية الحريسـة والحتميسـة

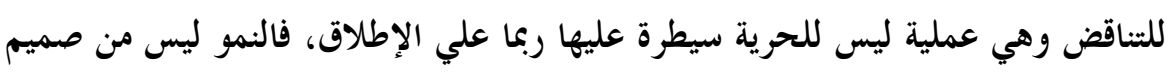

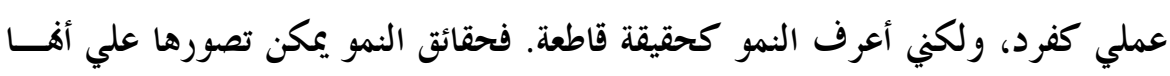

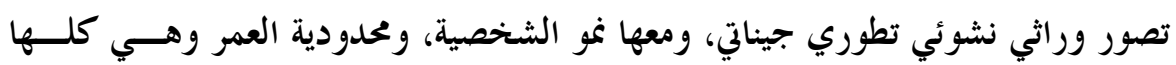
جوانب للحتمية أو الضرورة التي ما علي الحرية سوي الإذعان لها.

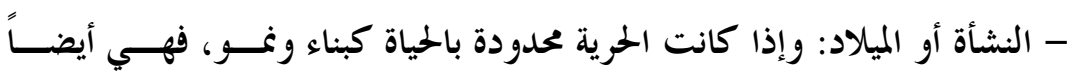

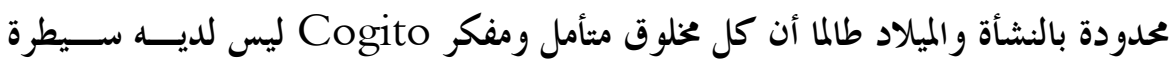

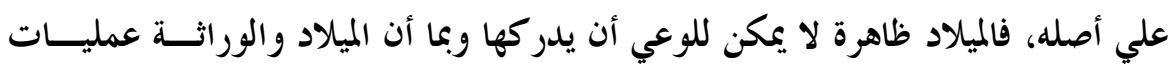

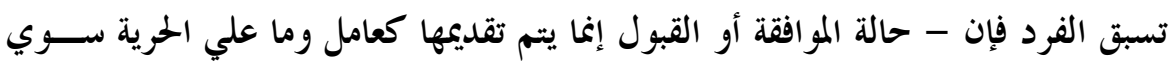

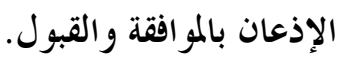

\section{ع - الحرية والطبيعة ومبحث ذاتية الجوهر :}

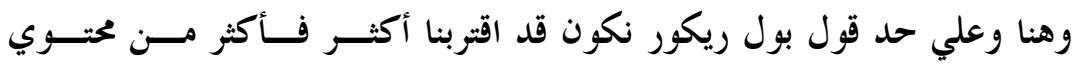

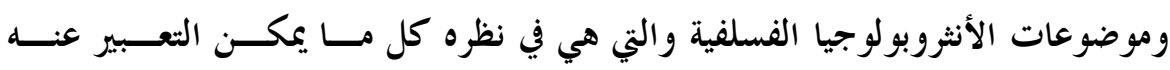

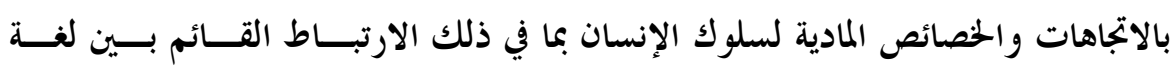

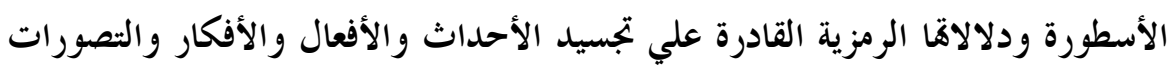

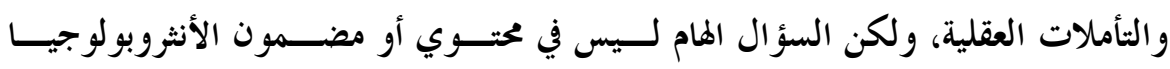


الفلسفية بما في ذلك ما يقره علماء الأنثروبولوجيا التقليدية حول أنثروبولوجيــا الجمســم وفلسفة ومغزى وجوده، وإنما السؤال الأساسي يكمن في مشكلة محتوي الطريقة المنهجية

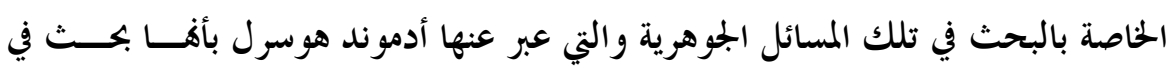

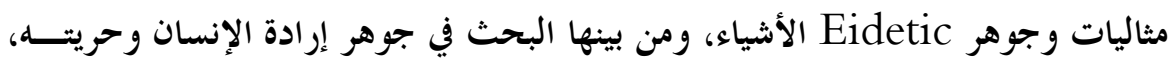

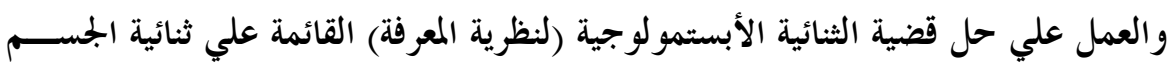

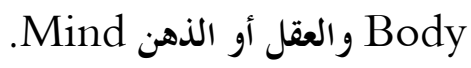

والجسم كجانب مؤسس للمعرفة مثله مثل العقل لأنه علي أساس الجسم العقلــي

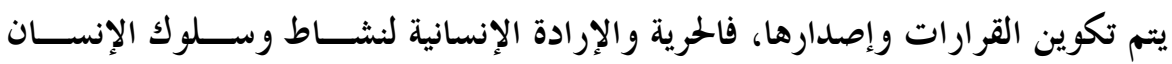
تتشكل بواسطة الجسم (أي الطبيعة)، وهنا يكون الجبر مرتبطاً بالاختيار، كما هي ثنائيسـة

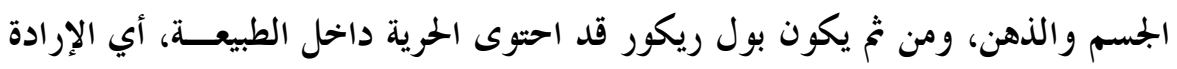
داخل الجسم، وفي ضوء ذلك الشمول يمكن إدراك النظرة الكونية أو العولميسـة Global

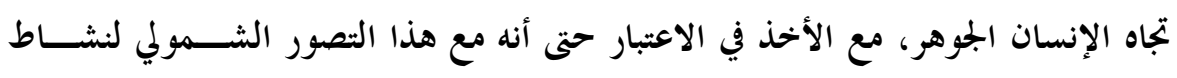

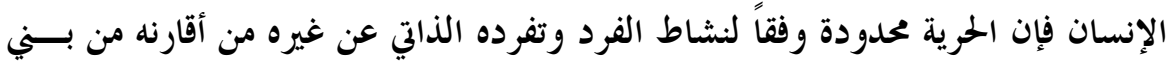

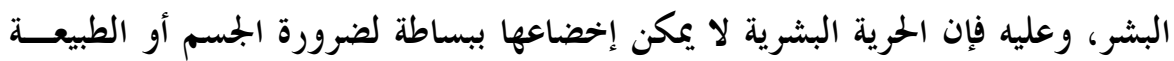

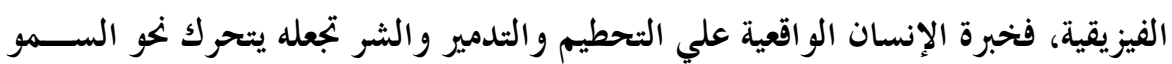
مما يعبر عن بعض الثناقض الواضح والحيادي - إلي حد ما - بين قضية الحرية والجسم أو ولئه

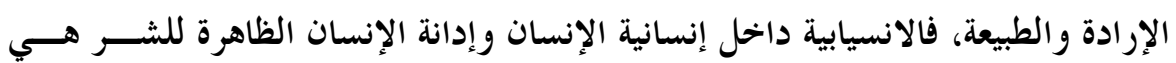

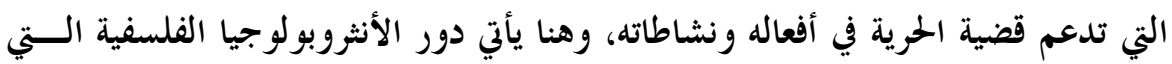
تسعي وتتم بالفهم الكامل للحرية (في ضوء خاصيتها الكونية أو العولمية).

Freedom and Fallibility ثانياً : الحرية و القابلية للخطائ

إن حر كة الانتقال من الوصف إلي حالة مبحث مثالية وجوهر Eidetic الأشــياء

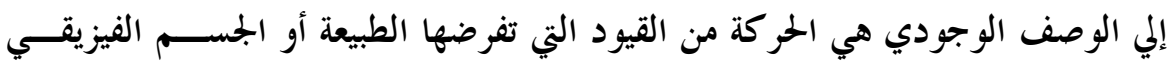

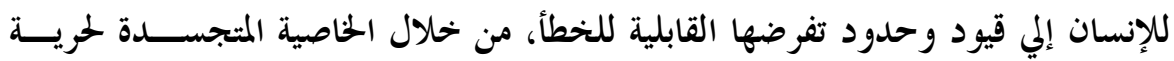

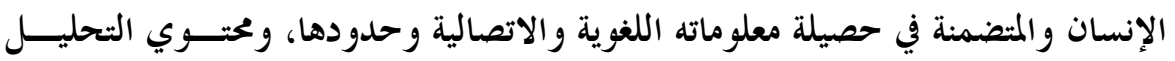


الوجودي لدي الإنسان، فهي منهجياً تنصب علي وجهة النظر الكلية للإنسان أو عولــــة

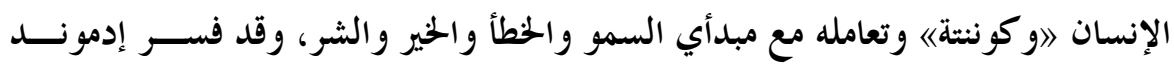

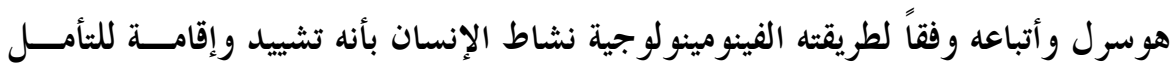

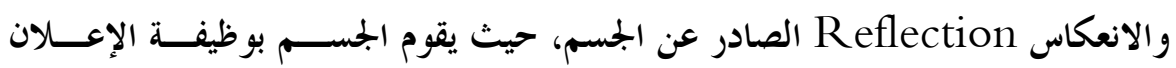

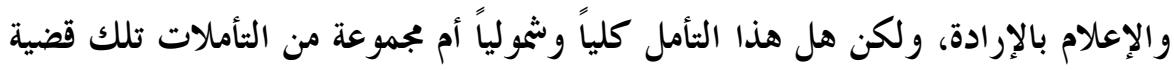

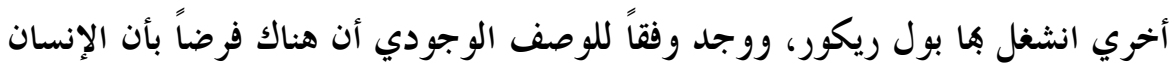

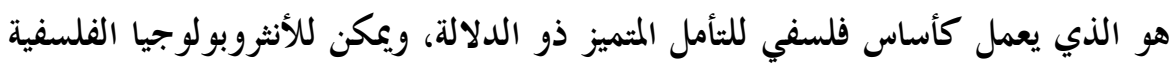

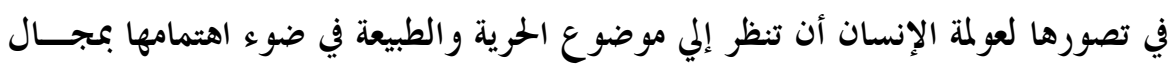

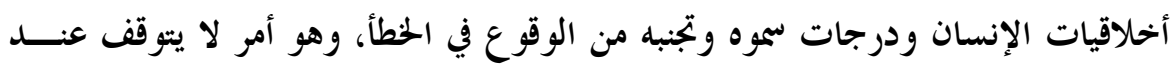
وعي الإنسان بالحرية، ولكن من خلال خبرة الإنسان ذاته.

ويظل هناك سؤ ال هام مؤداه: كيف يكتشف الفرد الحرية كجانب مكون للـــوعي

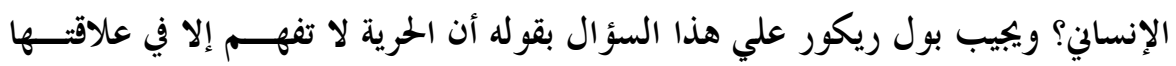
التبادلية مع الثر، والتي هي رؤية أخلاقية عن هذا العالم، وهذا التفسير يعتسبر المفتــاح

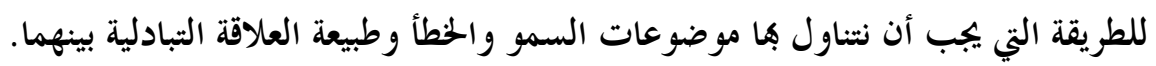
ومن هذا المنطلق قتم الأنثروبولو جيا الفلسفية بموضوع الحرية في علاقته بدرجات

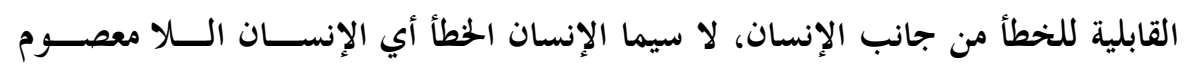
Fallibleman

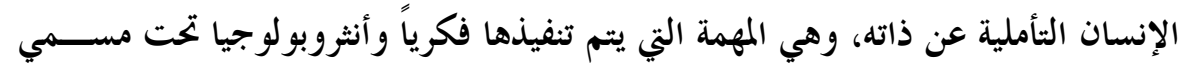

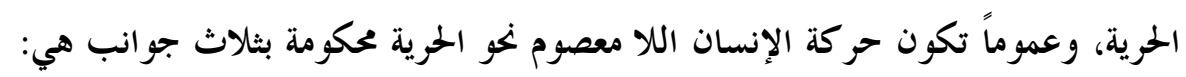

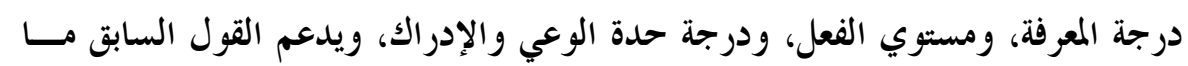
يلي Hypothetical التزعة الافتر اضية 
وهي القائمة علي أساس أن الإنسان بطبيعته هش وعرضة لاقتــــاف الإثم، وأنسـه ليس هناك تطابق للإنسان مع ذاته، وهي تلك الفرضية التي توضح أن القيان القابلية للخطأ هي خبرة معرفية، وعمل وشعور داخل الشعور.

r - نظرية المعرفة و القابلية للخطأ

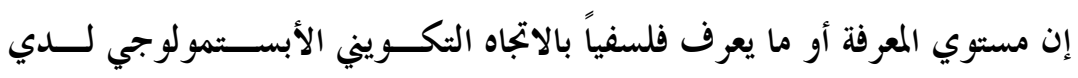

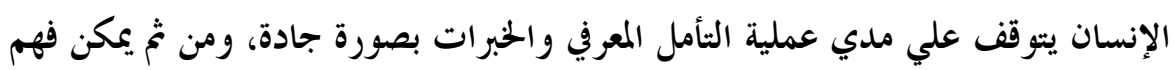

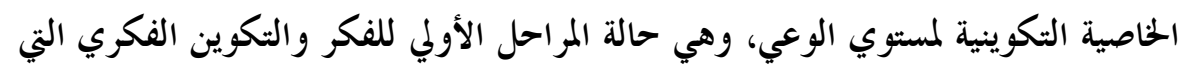

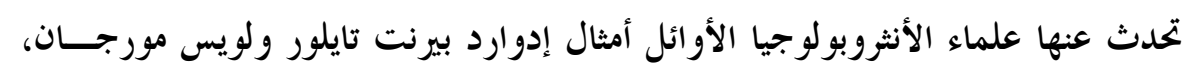

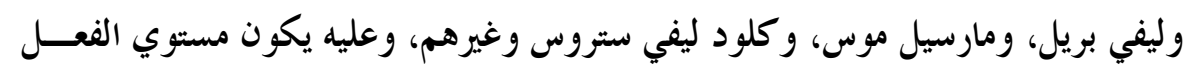

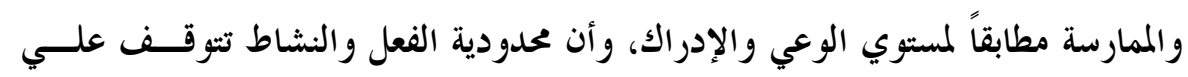

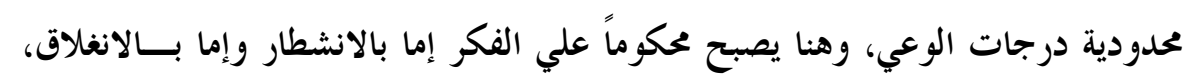

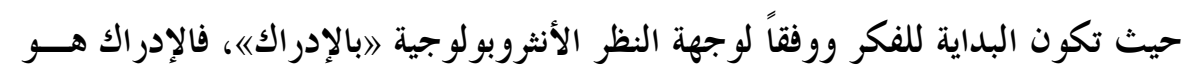

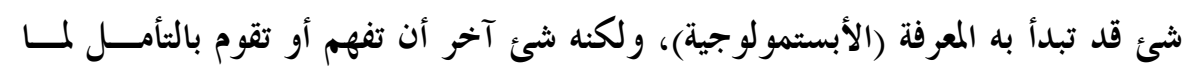

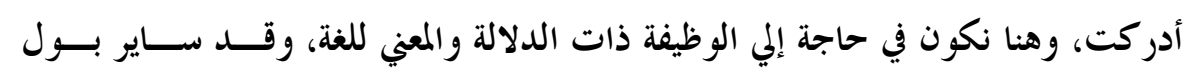

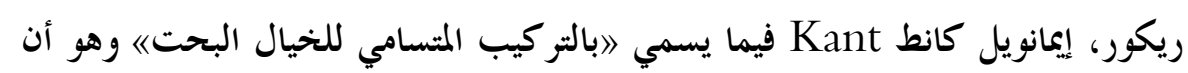

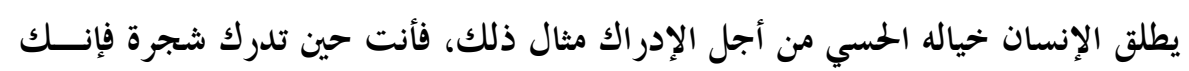

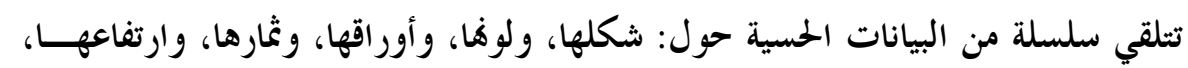

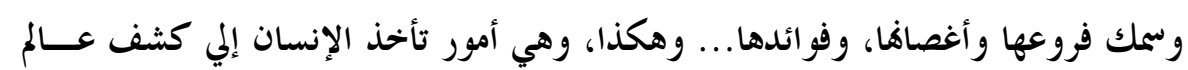

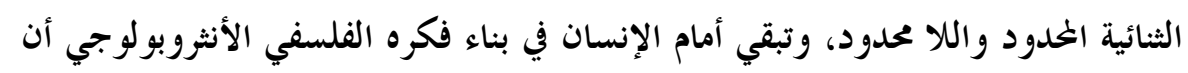

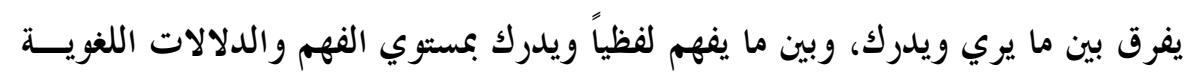

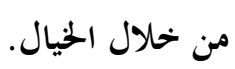

ب - الفعل و القابلية للخطأ

بينما يسعي المفكر الفلسفي في مجال الأبســمولو جي لإدراك مشــكلة الأســاس العقلي والفكري للوعي نجد أن الأنثروبولو جي الفلسفي ينظر إلي الأبنية الذهنية للإنسان 
ومدي قابلية الإنسان للخطأ من خلال الفعل والممارسة، وهي لا شك خاصية التفــاوت

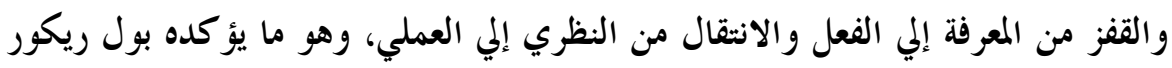

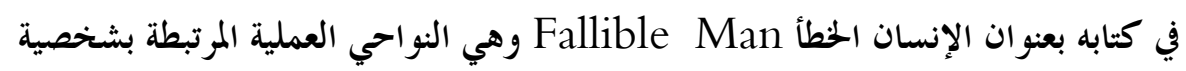

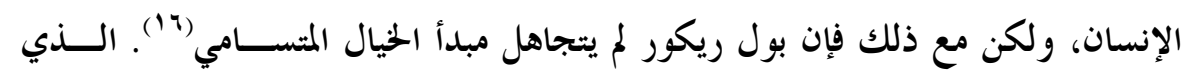

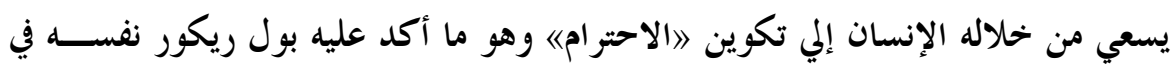

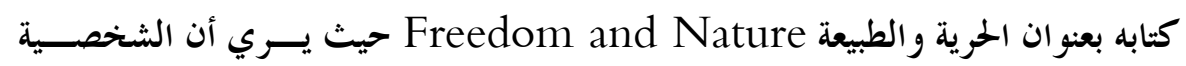

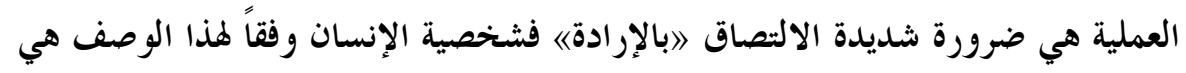

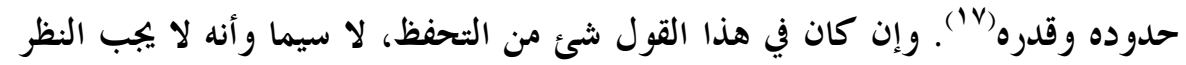

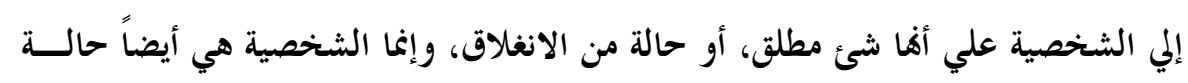
من الانفتاح الذي يجعل الحرية ممكنة. 


\section{عeeling - ع- الشعور}

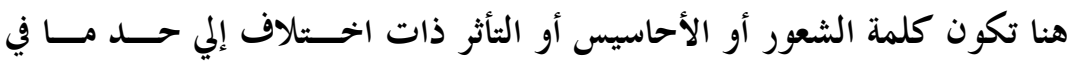

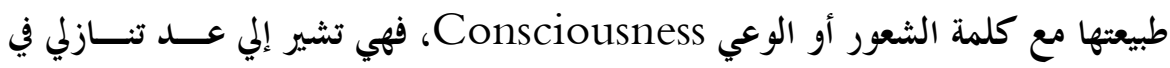
أحاسيس ورقة مشاعر الإنسان فهو يسمو من حالة الشعور بصفة عامة (وهي الوعي) إلي الي الئي

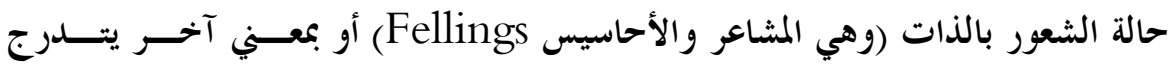

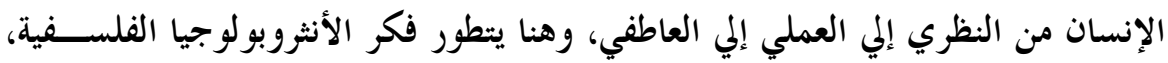

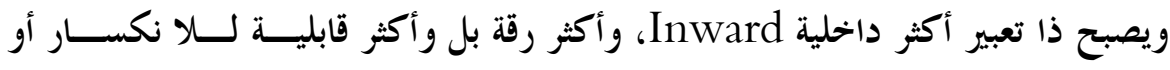

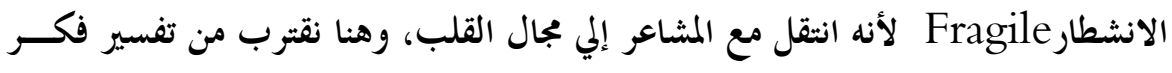

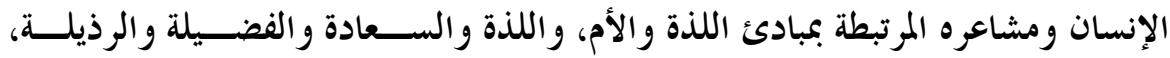

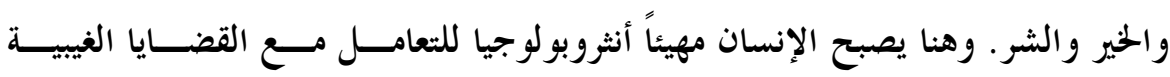

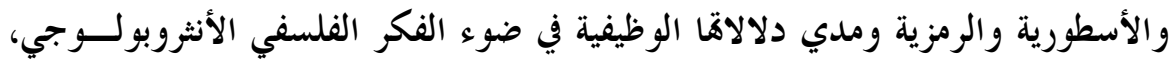

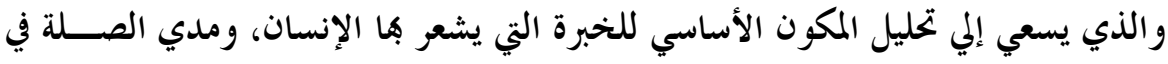

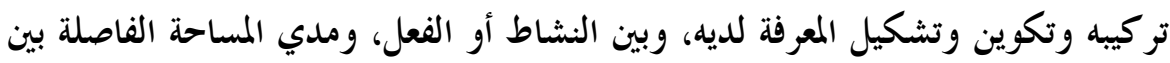
المعرفة والفعل والتي تعرف بخليط المثاعر أو الأحاسيس.

ثالثاً: الأنثروبولوجيا الفلسفية ورمزية الحرية واقتر اف الخطيئة:

يتضح من كل ما سبق أن موقف المفكر الفرنسي بول ريكور Paul Ricoeur

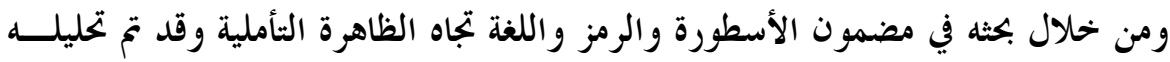
وتفسيره من خلال وجهتي النظر التأملية العقلية وحرية الفعل وممارسة الإنسان لسلوكياته

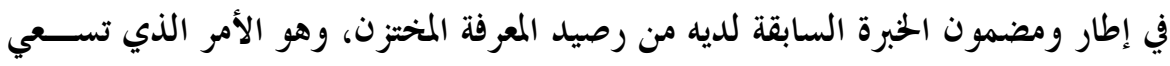

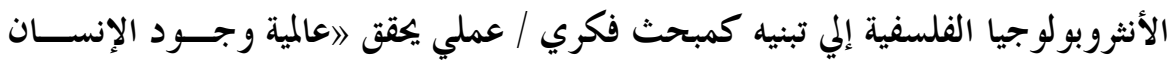

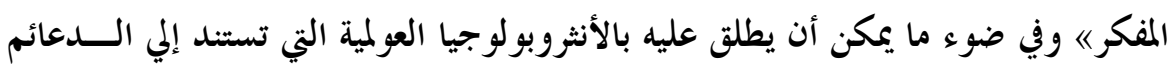

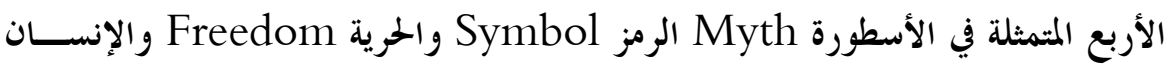
سواء المعصوم أو اللا معصوم Fillible Man من اقتراف الحطيئة. 


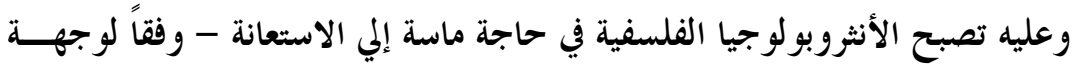
نظر بول ريكور - بمبحث مثالية الجوهر Eidetic Method من أجل تحقيق فهم جيد

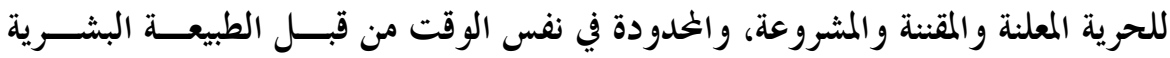

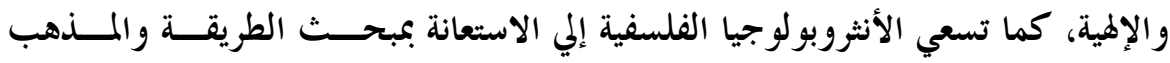

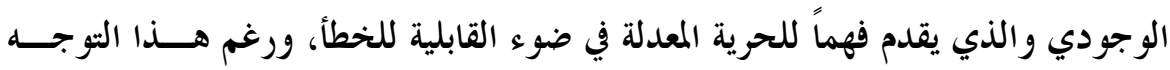

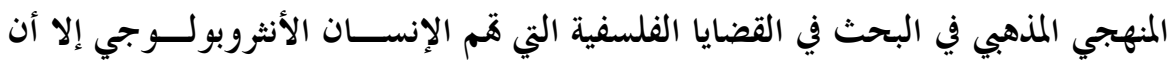

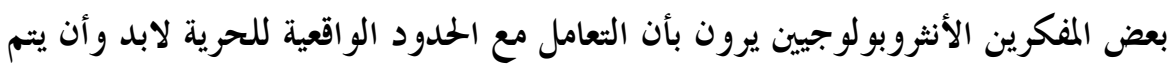

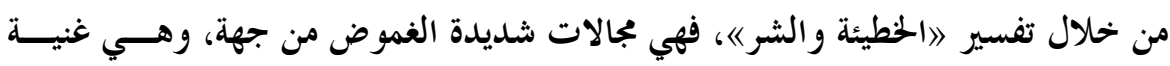

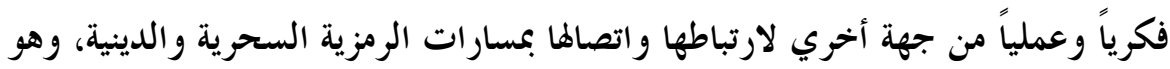

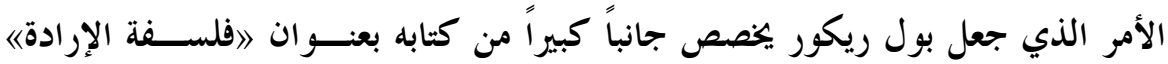

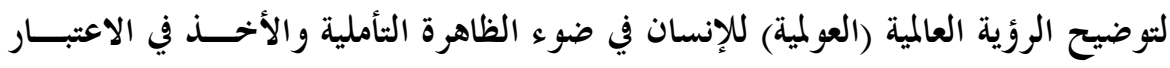

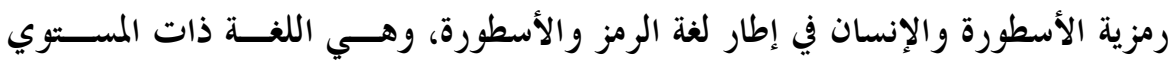

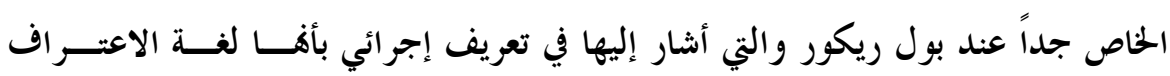
Avowal

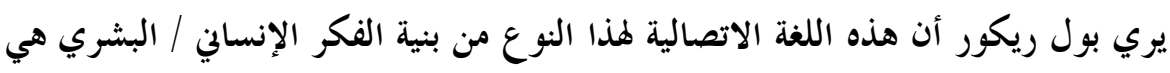
لغة قد تكون سابقة عن لغة الفكر الفلسفي الحديث والمعاصر، بل والفكر الفلسفي الغابر

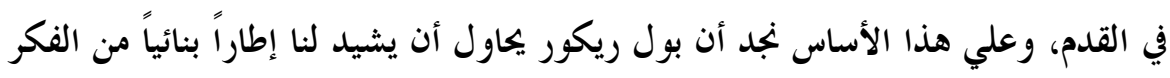

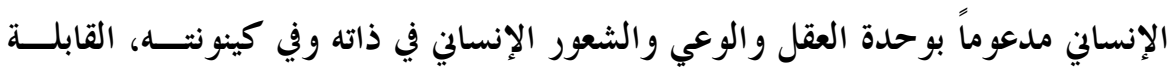
للخطأ، وفي حدود التعامل مع الإمكانات Possibilities المتاحة فقط. ويشير بول ريكور إلي ثلاثة أنواع من اللغة الاتصالية في حالة تفسـير الخطيسـة أو

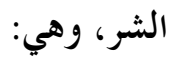

1 - اللغة الأساسية المرتبطة بالرموز، وهي الأكثر جوهرية ومركزية للتعبير عــن

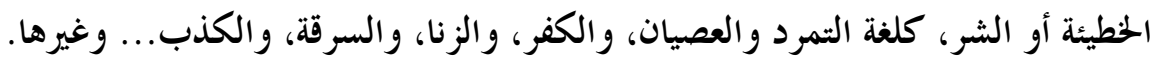


Y - لغة التفسير الرمزي في الأسطورة والتي تعتمد علي الرموز الجوهرية داخــل

$$
\text { الأسطورة، مثل حالة جبروت الأب في أسطورة أوديب. }
$$

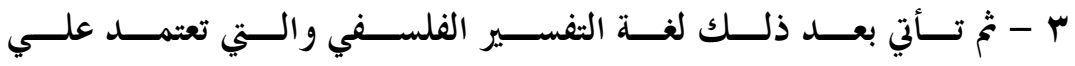

التأويلات Hermeneutics أساساً في تناولها لمشكلة الشر.

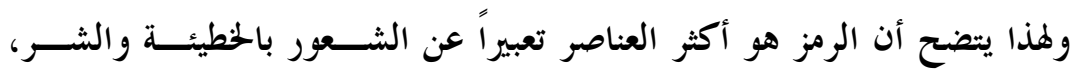

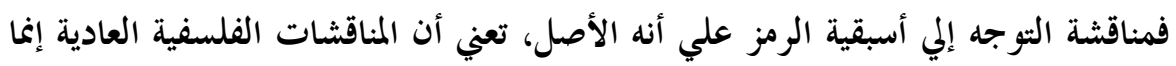

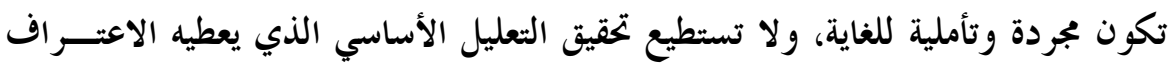

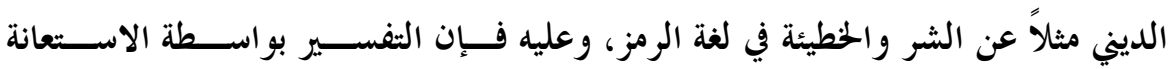

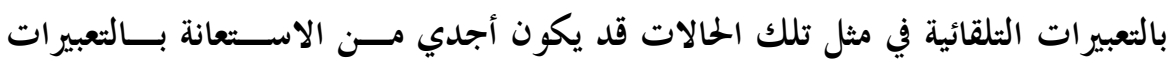
التأملية، كما ركز بول ريكور من جانبه علي ضرورة البحث فيما وراء التعبير العقـلاني

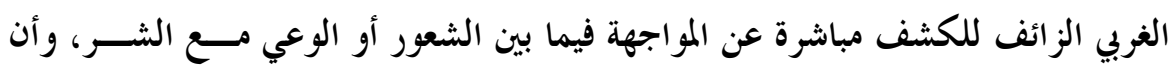

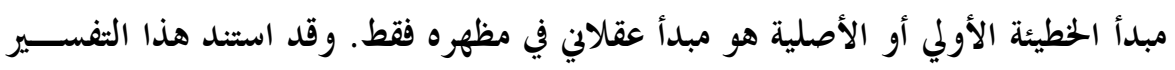

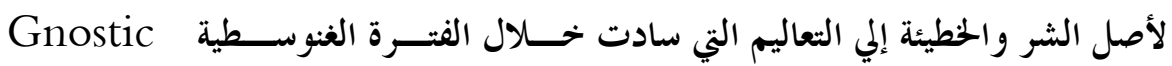
Period

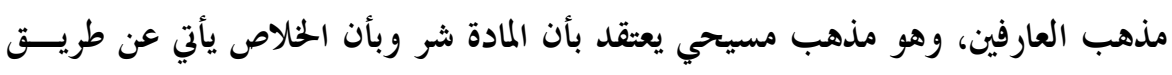

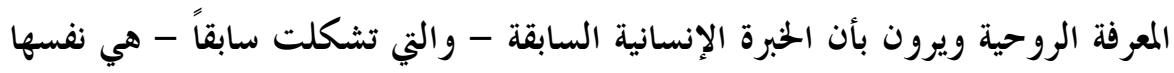
التي تسهم في التفسير، بل هي وحدها القادرة علي تنمية الشعور بالوعي والثفرقة ما بــين التهائ

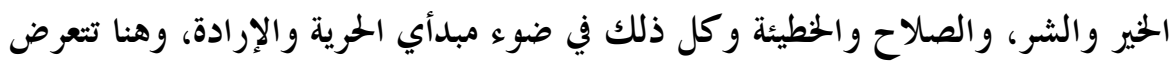

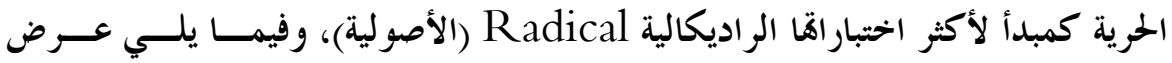
لبعض النقاط التي تشير إلي تلك الاختبارات : أولاً : الرمز والإرادة المستسلمة:

جاء من خلال اهتمامات بول ريكور بالبحث عن الرمز Symbol فيمـأسيساه

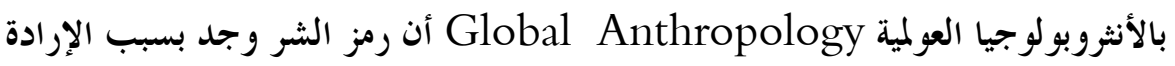

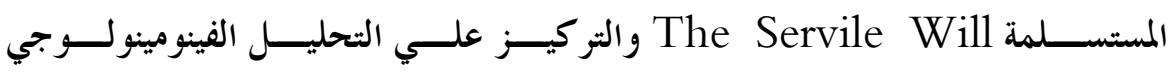


Phenomenological Natural Phenomena

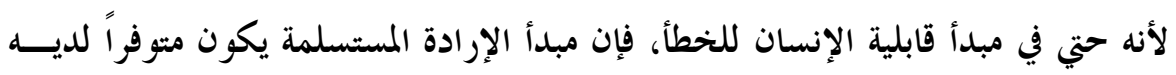

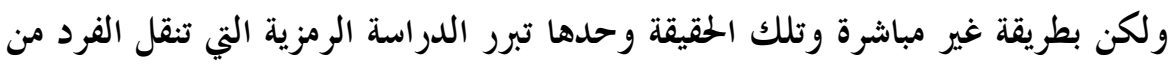

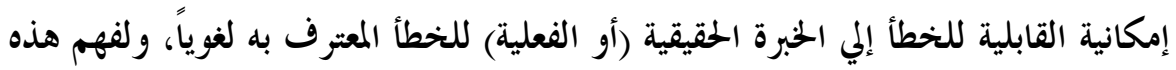

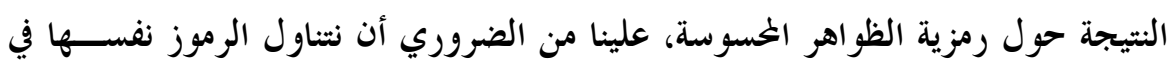

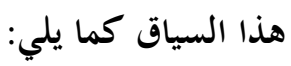
1 - بقعة أو وصمة الشر Stain أو 》التلطخ) بالخطيئة والذنب، وهنسـا تكسـون

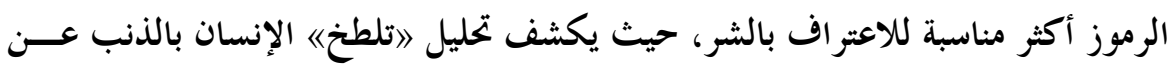

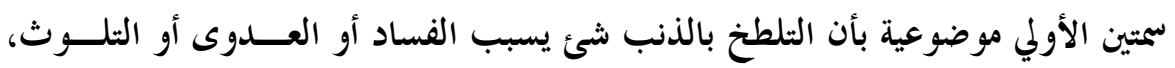

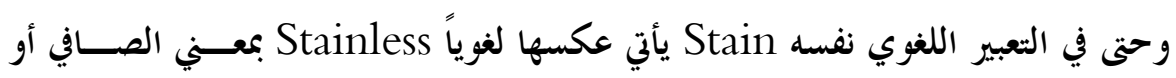

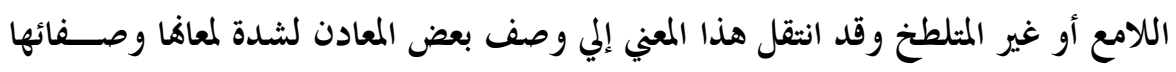

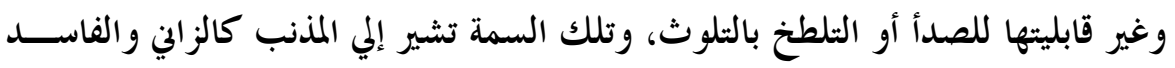
والكاذب والكافر أو الملحد وغير ذلك.

أما السمة الثانية للتلطخ فهي ذاتية وهي تشير إلي 》الذنب) نفسه أو الشر نفسـهـ كشئ مرعب ومخيف كالكفر والإلحاد والزنا، والسرقة والنجاسة وغيرها، وعندئذ يسأني

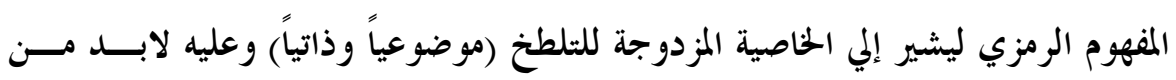
تنقية النفس من الحوف والرعب التي ترمز له هذه البقعة.

r - كin حيث رمزية اقتراف الإثم أو الذنب ذات علاقة قديمة بالحطيئة،

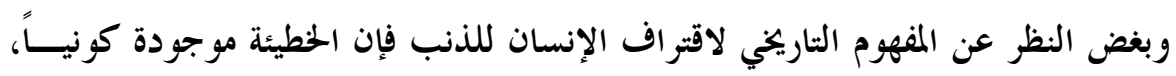

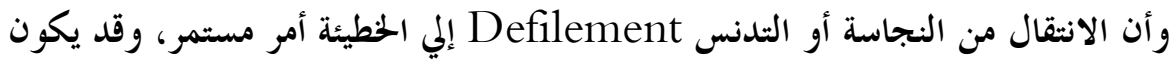

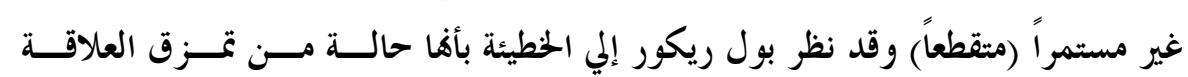

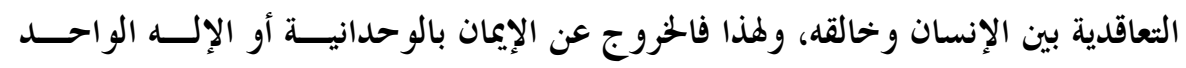


Monotheistic وذاتياً أمراً لا فاية له طالما وجد الإنسان بمفهومه الأنثروبولو جي (العملي).

r r Guilt يشير الذنب إلي كمية متصلة من النقاط الخارجية والداخلية

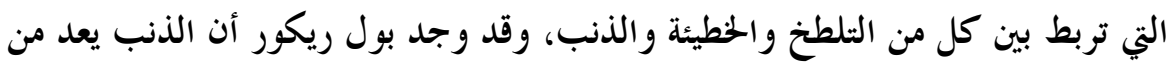

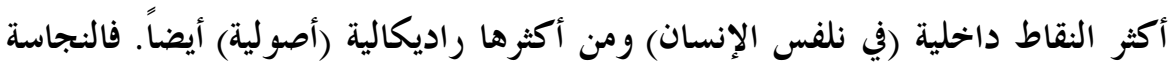

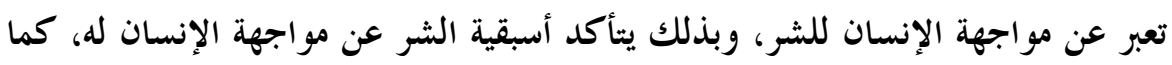

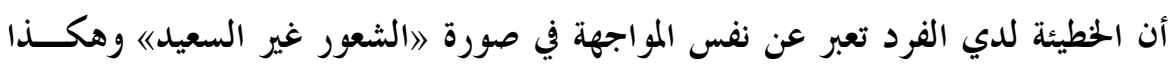

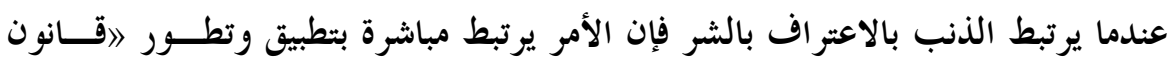

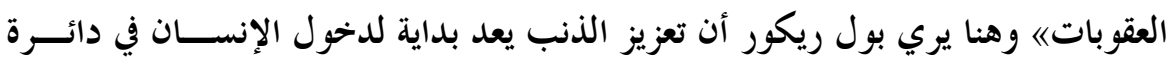

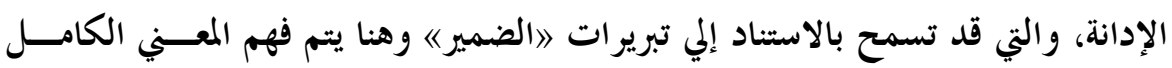

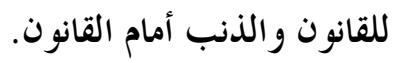

وهكذا فتحت المبادئ السابقة الجمال للمناقشة في إمكانية وصول الفرد لمبدأ الحرية

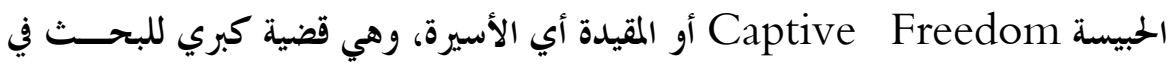

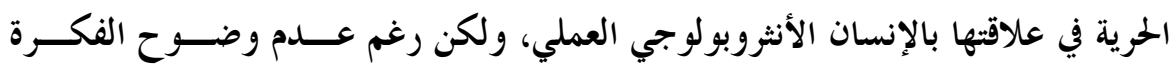

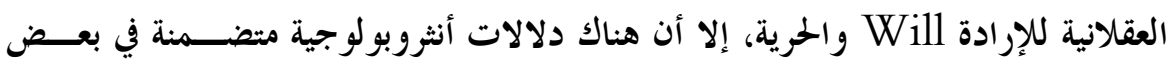

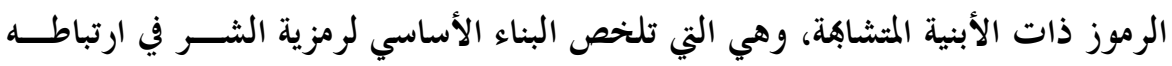
بالإرادة المستسلمة أو الحرية الحبيسة في ضوء الخصائص التالية:

1 - إن الخطيئة أو النجاسة توضح أن الشر ليس عسـدما Annihilate، وأنسه. واجب الوجود لأنه شئ يتم عمله وتحقيقه سواء من المنظور البشري أو الإلهي. Y - ينظر إلي الشر علي أنه شئ يأتي للإنسان من خارجه، أي أنه شــئ مقـــدم الوجسـود علي وجود الإنسان، وبذلك يكون للشر بناء يشارك فيه الإنسان.

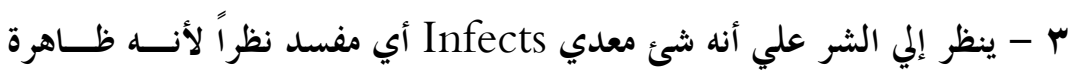


وتتضح رمزية تلك الخصائص من خحلال النظر إلي الإنسان ومدي قابليته للخطــأ،

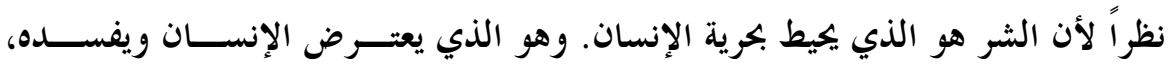
وبالتالي يحد من قدرته علي الحخير الذي قد يختاره، وقد نظر علماء الأنثروبولوجيا الفلسفية

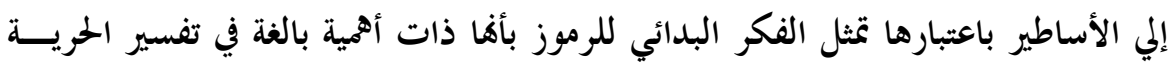
وعلاقتها بإقتر اف الشر. رابعاً : الأنثروبولوجيا الفلسفية والأسطورة: يخطئ من يظن أن الأساطير ما هي إلا حو اديت وحكاوي تروي مـــن النــاس إلي الناس دون هدف من ورائها سوي قطع الوقت والقضاء علي وقت الفراغ بالتسلية، كما

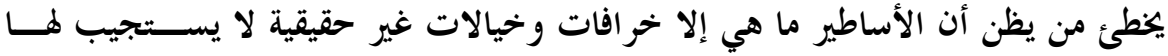

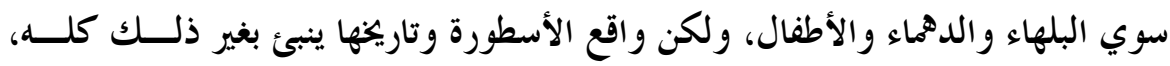

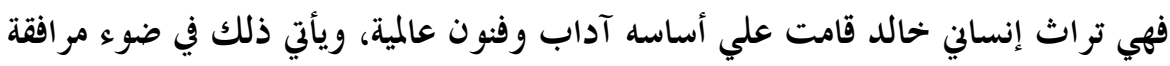

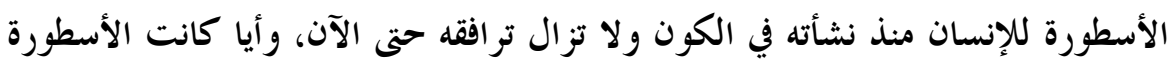

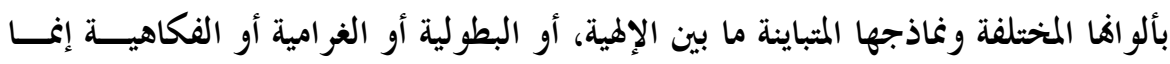

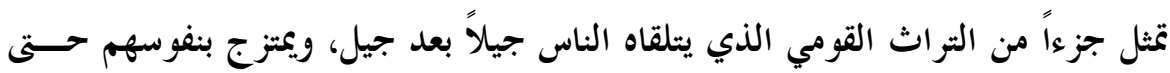

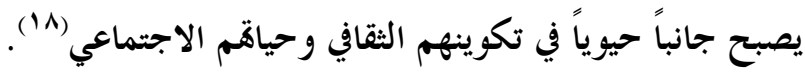
وأغلب الأساطير تدور حول إقامة وإنشاء حياة أفضل للإنسان، وهي محسـاولات

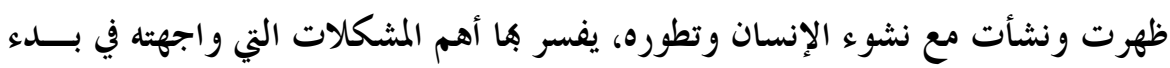

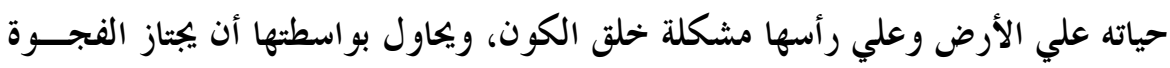
والهوة بين العالم الذي يعيش فيه و الكون الغامض الذي يحيط به، فيحاول عــن طريقهـ

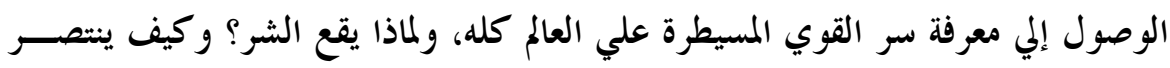
الحير؟ وإذا كانت الأسطورة تحوي كماً وحجماً لا بأس بهما من الغموض والأسرار التي تكتنف معني واستخدام مصطلح الأسطورة Myth والحكاية الأسطورية Legend وأيا

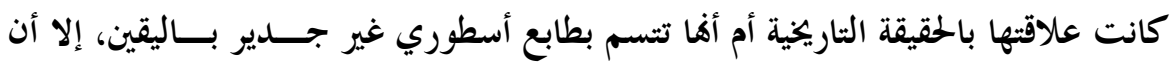


استخدامنا لمفهوم الأسطورة وتحليلها أنثروبولوجيا وفلسفياً إنما ينطوي علي معايير وظيفية

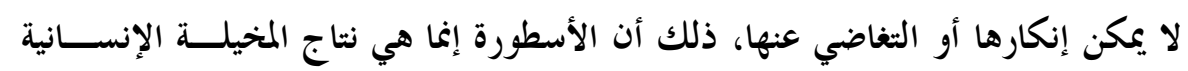
Human Memory الاختلاف في وجهات النظر حول تعريفها ونماذجها المختلفة والوظيفة أو الوظائف الـتئي تؤديها. ولما كانت الأسطورة أكثر ارتباطاً بتفسير العلاقة بين الثر والخحير، فقـــد جـــاءت مناقشات بول ريكور Paul Ricoeur حول تعريف الأسطورة باعتبارها فكراً بـــائياً

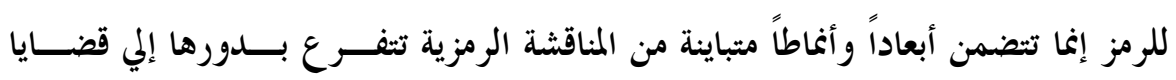

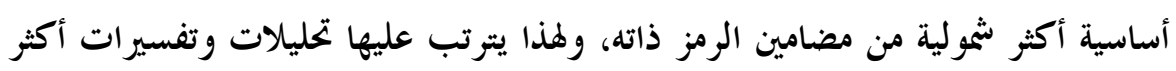

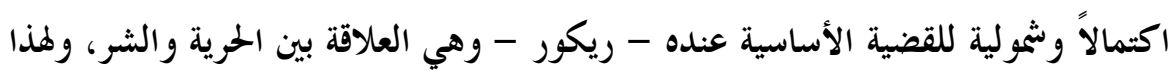
ينظر ريكور إلي تعريف الأسطورة بأفا تتضمن القضايا والأسس التالية:

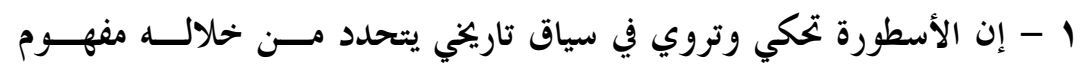
الإنسان والإنسانية، فيصبح كل منهما نموذجاً تاريخياً لحالته ودالته. r - إن الأسطورة تحكي قصة أو راوية تجمع بين الحرافة والتاريخ. r- تحاول الأسطورة شرح الأحاجي Riddles وتفسير لغز Enigma التاريخ

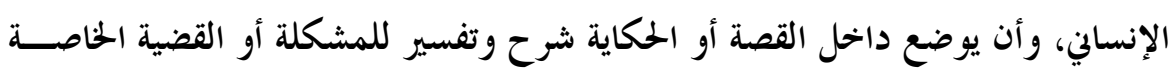
بالإنسان.

هذا وقد وقف بول ريكور منذ البداية موقفاً حاســـاً في نظرتسه إلي الأســطورة

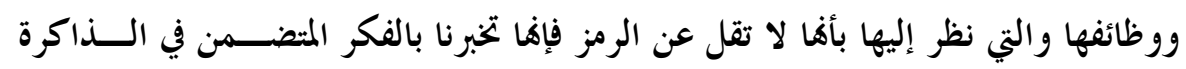

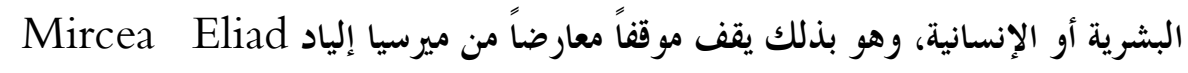

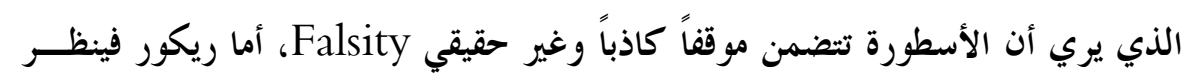
إليها بأنها حديث ذو معني، فالأسطورة في رأيه، ومن خلال النمو الفكري (التأملي) يمكن

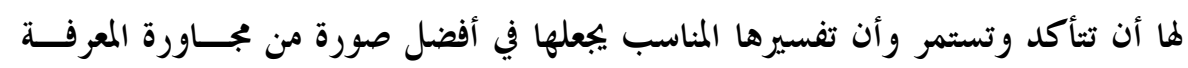
الروحية) (19) 


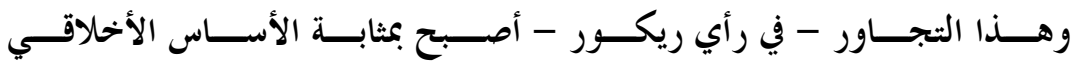

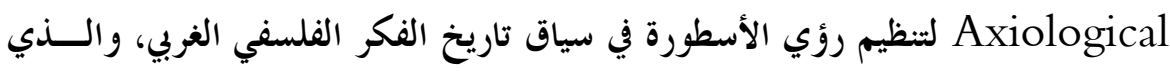

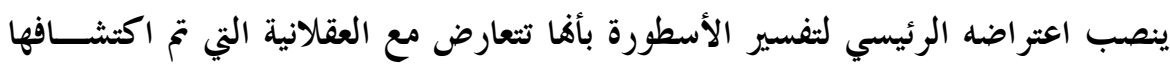

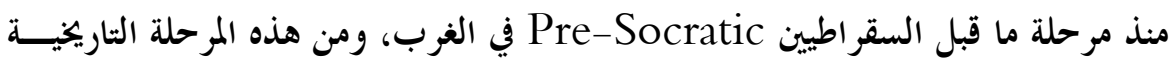

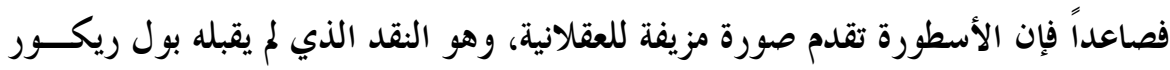

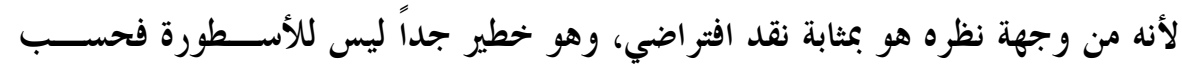

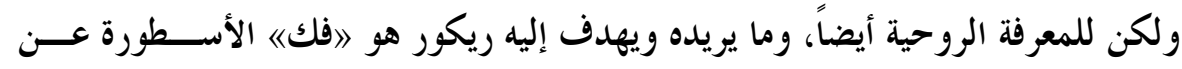

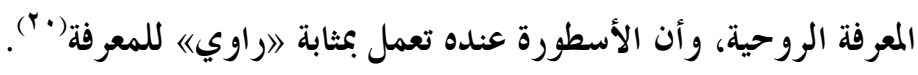
ودراسة الأسطورة عند بول ريكور لا تتركز علي دراسة الأسطورة بصفة عامسة،

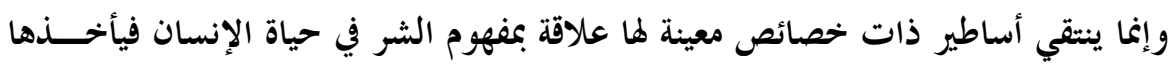

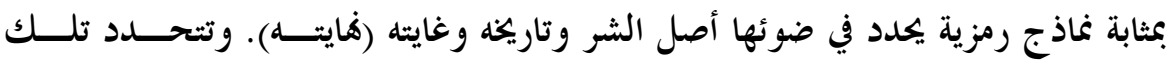

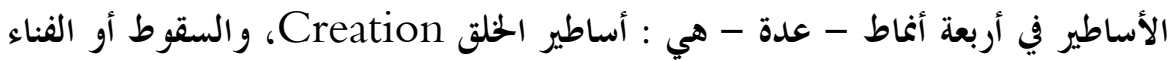

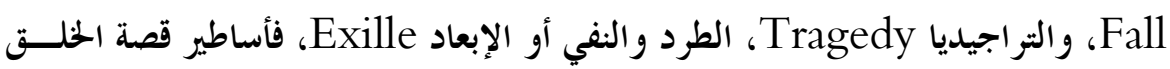

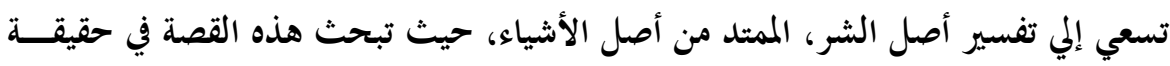
الأساطير، وحقيقة خالق الأساطير نفسه (الإنسان) منذ نشأته، حيث عاش الش أول ألماند أمره حياة

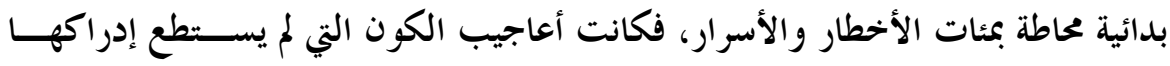

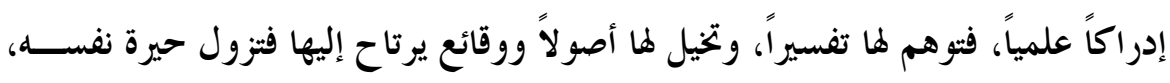

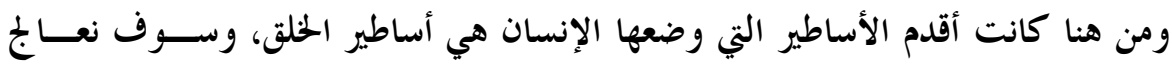

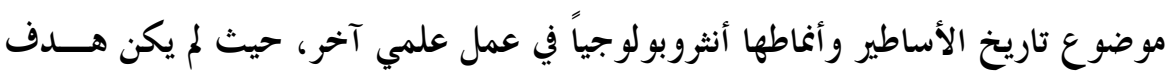

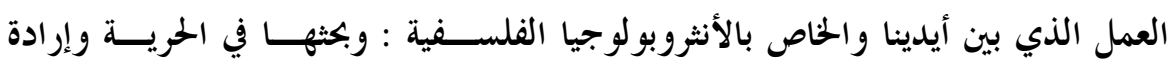

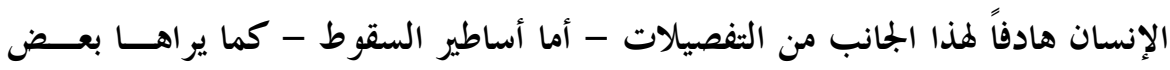

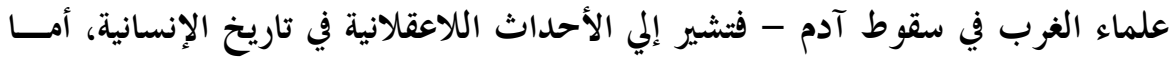

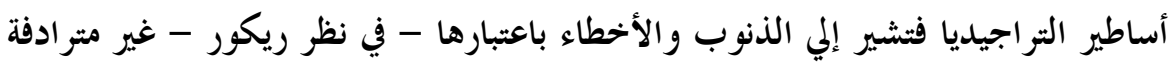

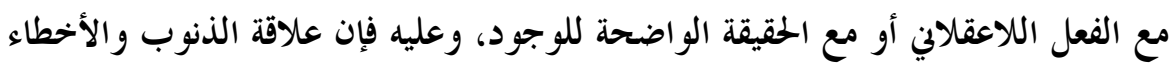

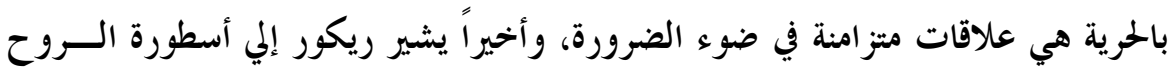




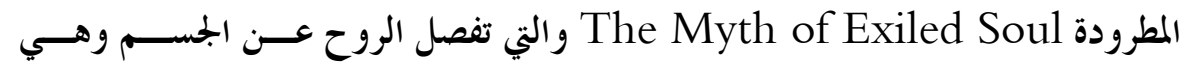

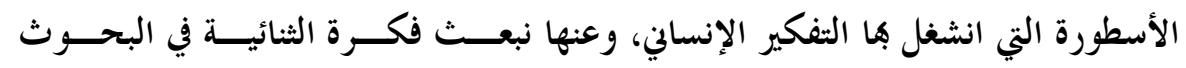

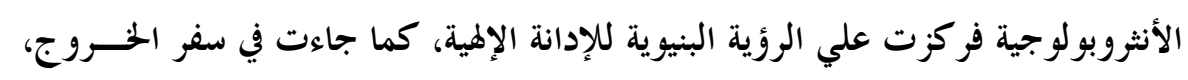

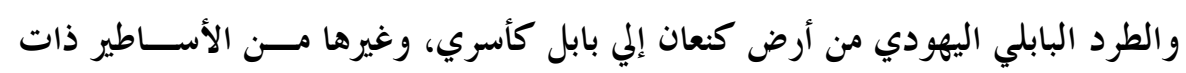

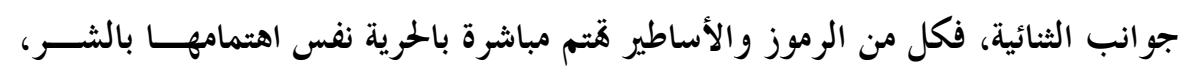

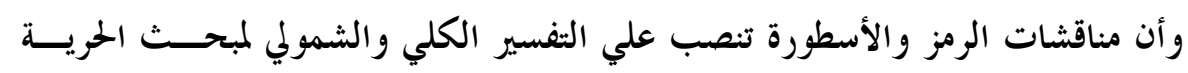

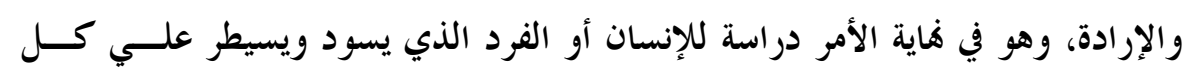
موضوعات الأنثروبولوجيا الفلسفية. 


\section{المراجع و الهو امش : المش

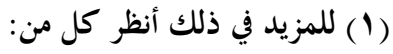

- قباري محمد إسماعيل، الاتجاهات المعاصرة في مناهج علم الاجتماع، دار الطلبة العرب،

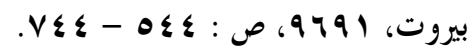

-Karl Mannheim, Essays on Sociology of Knowledge, Routledge \& Kegan Paul, London, 1962, pp. 7 - 9.

$$
\begin{aligned}
& \text { (ץ) أنظر عرضاً لتاريخ ونشأة الأنثروبولوجيا الفلسفية واهتمامات البحث فيها وأهم روادها } \\
& \text { من علماء الفكر والفلسفة والاجتماع والأنثروبولو جيا في : }
\end{aligned}
$$

-Philosophical Anthropology, in Encyclopedia of Philosophy Edited by : Paul Edwards, The Macmillan Company \& The Free Press, New York, 1967, Vol. 5, pp. 159 - 166.

$$
\begin{aligned}
& \text { (广ّ) للمزيد حول اهتمامات الأنثروبولوجيا الفلسفية بالجوانب البيولو جية للإنسان، لا سيما ما }
\end{aligned}
$$

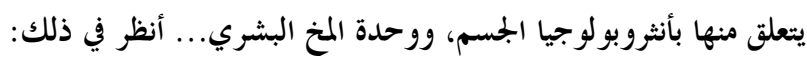

-Stuart F., Spicher, (ed); The Philosophy of the Body, Quadrangle Books, Chicago, 1979.

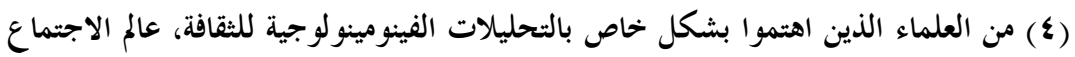

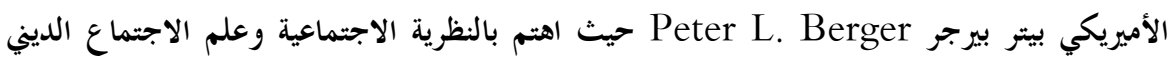

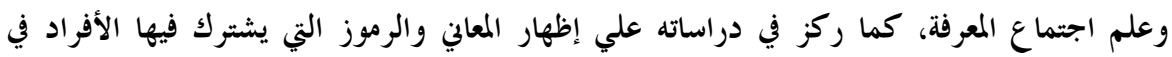

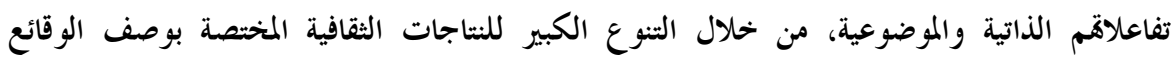

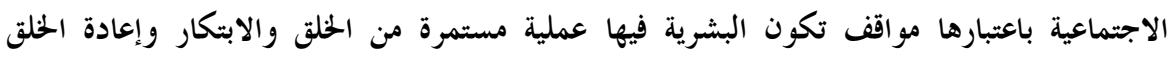

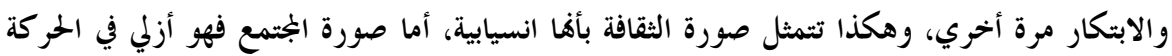

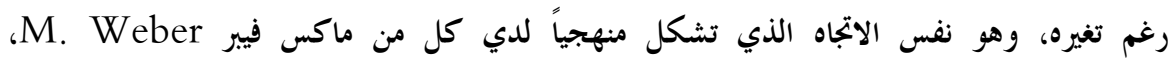

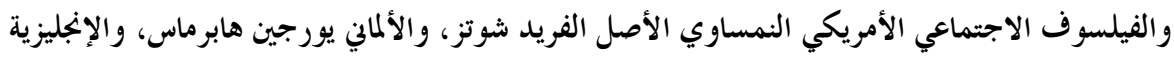

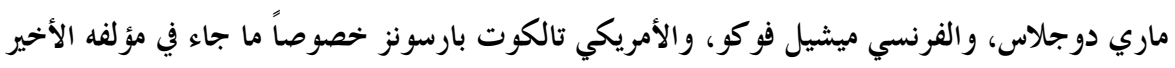

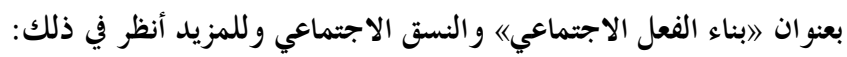


- Robert Wuthnow and Others: Cultural Analysis: The Work of Peter L. Berger, Mary Douglas, Michel Foucoult and Jurgen Habermas, Routledge and Kegan Paul, London, 1984, (1987.)(

(•) عبد الله عبد الرحن يتيم، كلود ليفي ستروس: قراءة في الفكر الأنثروبولوجي المعاصر،

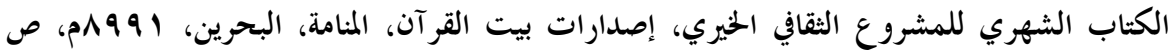

(1) للمزيد حول الآراء والتصورات التي قدمها المفكر الفرنسي وعالم الإنسانيات المعاصر بول

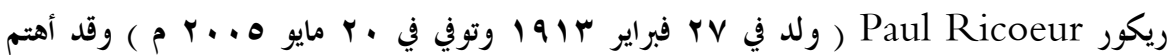
ريكور بالمذهب التأويلي والبنيوية ويعد امتداداً لفرديناند دي سو سير ، ولمزيد عن فلسفة الإرادة عنده

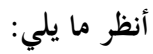

Paul Ricoeur, "The Hermeneutics of Symbols and Philosophical Reflection" International Philosophical Quarterly, II, No. 2, 1963.

Freedom and Nature: The Voluntary and the Involuntary, Trans., By, : Erazim V., Kohak, Northwestern University Press, Evanston, 1966.

The Symbolism of Evil, Trans. by, Emerson Buchanan, Harper and Row, London, 1967.

Cultural Hermeneutics

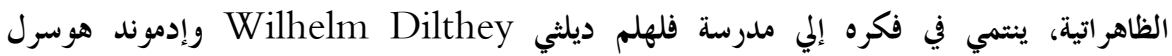

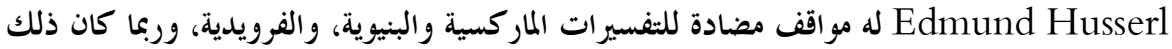

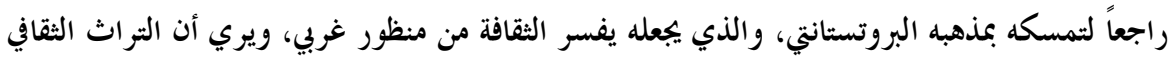

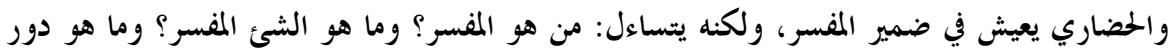

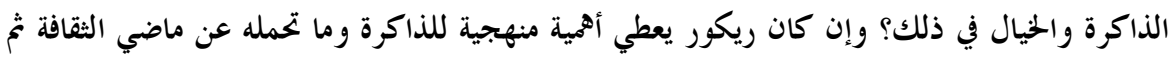

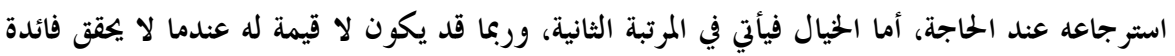


اتخذت المعرفة أو الأبستمولوجيا Epistemology علي يد أنصارها طرقاً ومذاهب عدة (V) منها علي سبيل المثال:

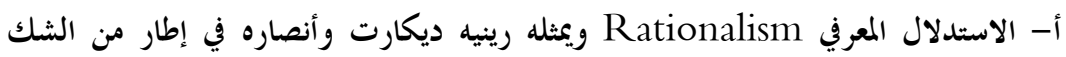

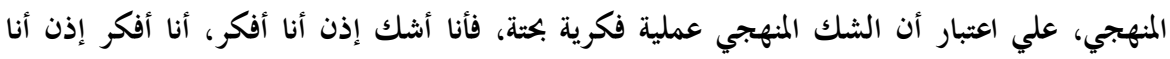

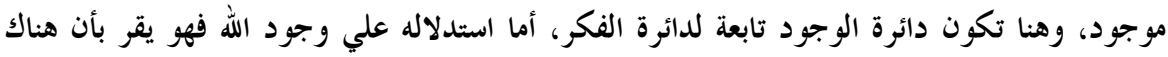

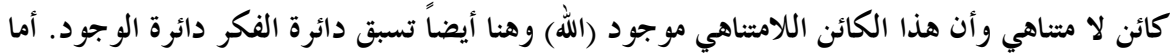

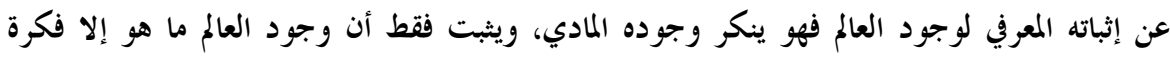

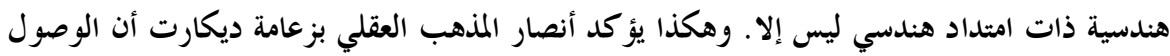

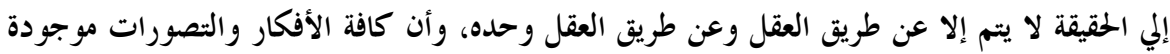

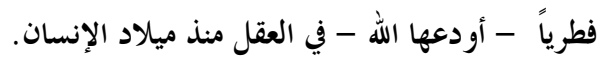

ب - الاستدلال المعرفي التجريب Empiricism وهو القائم علي فلسفة الملاحظة

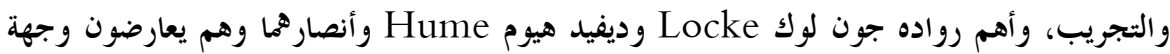

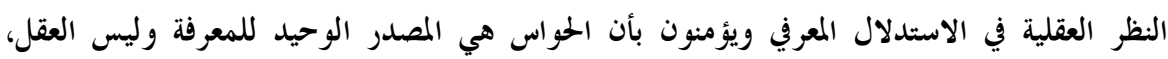

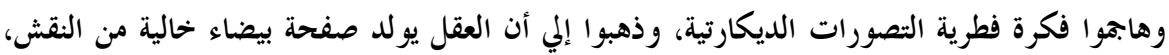
والحبرة والمعرفة، وأن العقل يكتسب معارفه عن طريق الحواس، وإن كانت هذه المدرسة الفكرية قد المدان

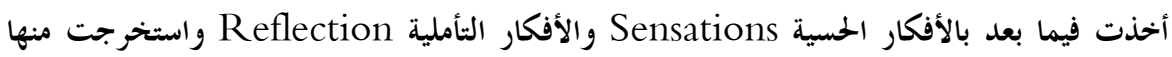

$$
\begin{aligned}
& \text { أفكاراً مر كبة تجمع بين الحسي والتأملي. }
\end{aligned}
$$

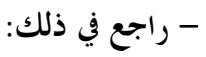

- Locke, J., An Essay Concerning Human Understanding, London, 1690.

- Hume, D., An Inquiry Concerning Human Understanding, London, 1748 .

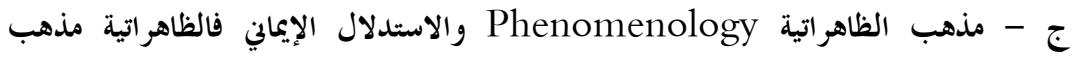

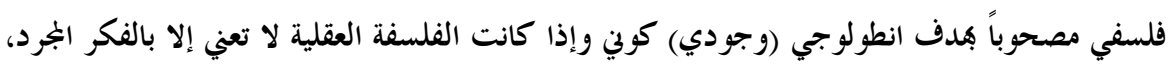

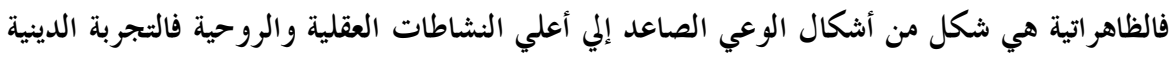

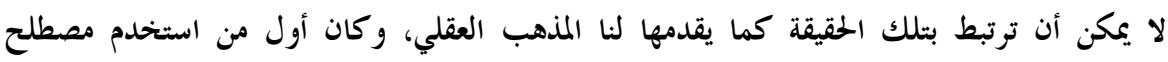

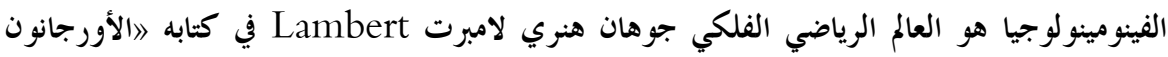

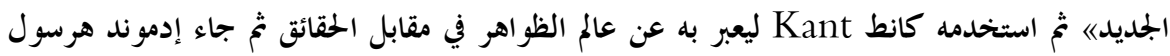


Ided, وطور من مفهوم الفينومينولوجيا في كتابه بعنوان (Edmund Husserl (9581 - 8391 General Introduction to Pure Phenomenology إقامة مذهب فلسفي وصفي يصف بإسهاب وعمق كافة الموضوعات في ماهيتها كما يراها المشاهد نفسه.

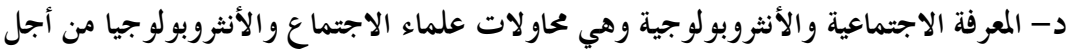

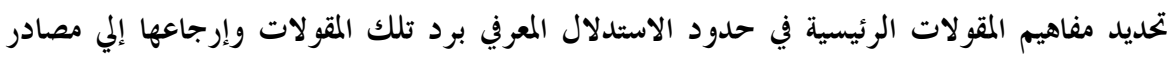

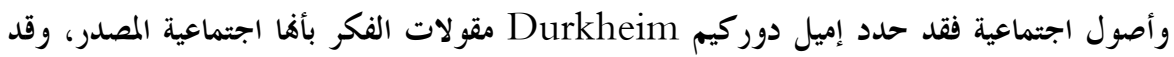

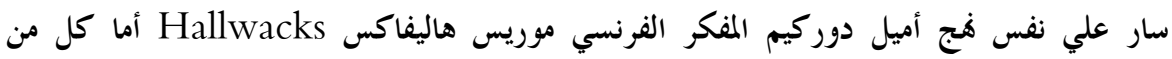

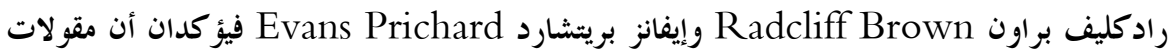
الفكر تعود إلي الحياة الاجتماعية والارتباط بالنسق البنائي للمجتمع. - راجع في ذلك : -

- Kurkheim, E., Les Formes Elementaires de Lavie Religieuse, Paris, 1912.

- Radcliff - Brown, Andaman Islanders, Free Press, London, 1948.

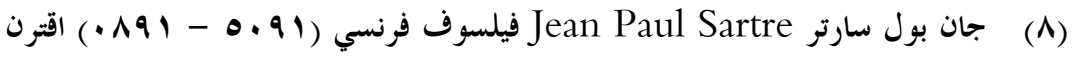

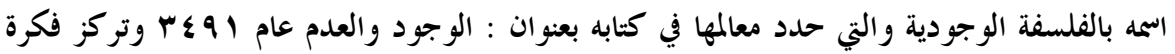

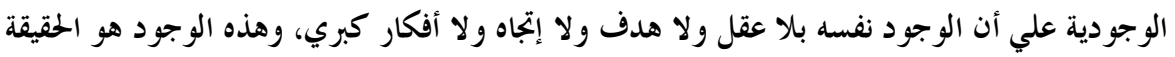

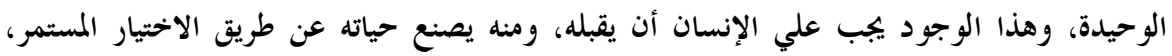

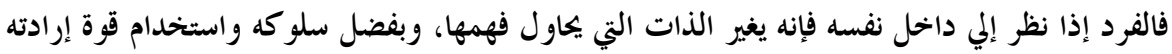

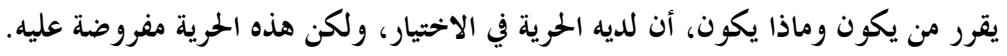

فمفهوم الحرية عند سارتر ليس معناه أنني حر تقاماً، ولكن معناه أنني حر في اختيار ما يعجبني

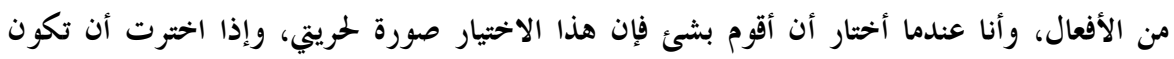

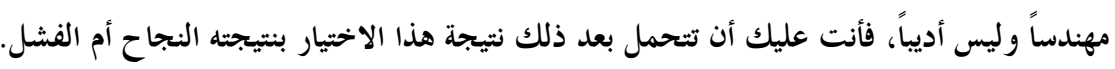
الإنسان إذن وحيد في الكون، ليس له ما يعتمد عليه إلا نفسه (وهذا قول الوجودية الذي

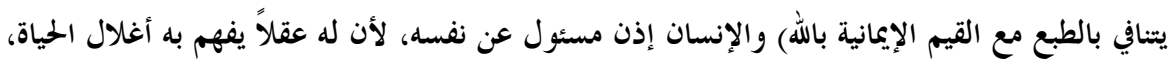
وله إرادة عاقلة يحطم هما هذه الاغلال، كل ما في الطبيعة عبد مسير إلا الإنسان، فهو وحده مخيز، ولها عقل فهو مختار، وهو إذن مسئول عن نفسه وعن إخوته في الإنسانية.

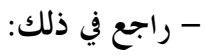


- - هنري توماس ودانلي توماس، أعلام الفكر الأوروبي، الجزء الثاني، ترجمة عثمان نويه،

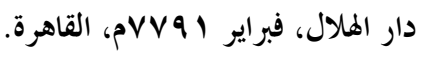

-Jean - Paul Sartre, Being and Nothingness, Washington Square Press, New York, 1966.

(9) يشير مبحث ذاتية الجوهر أو المثفرد، كما جاء في قاموس الفلسفة علي النحو التالي:

-Eidetic : (Ger. Eidetisch) In Husserl: Of or Pertaining to an eidos or to eide. Eidetic Existent: Anything falling as an example within the ideal extension of a valid eidos, e. g., an ideally or urely possible individual, (Purely) eidetic judgments: Judgments that do not posit individual existence, even thoug they are about something individual, Eidetic necessity: an actual state of affairs, so far as it is a singularization of an eidetic universality. E. G., This color has (This) brightness, so far as that is a singulariztion of all eidetically possible examples of color have brightness, Eidetic possibility : See Eidos, Eidetic reduction: See Phenomenology.

- تترجم بأفا طريقة منهجية بحثية في مثاليات جوهر الأشياء - وهي من اجتهاد المؤلف -

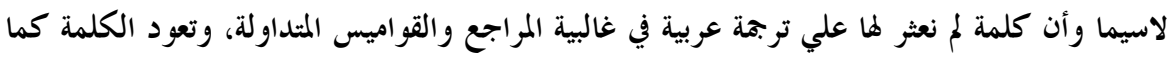

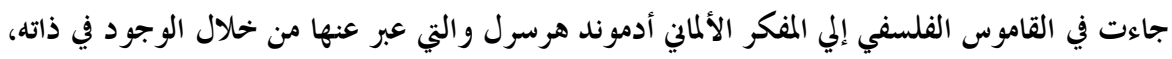

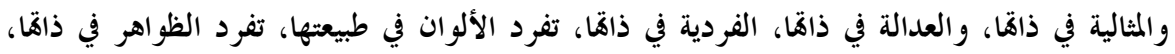

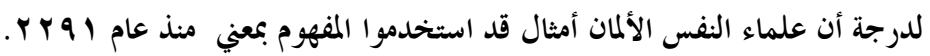
(1) (1) للمزيد حول آراء ميرلو بونتي أنظر:

-M. Merleau - Pontym: Phenomenology of Perception, Routledge and Kegan Paul, London, 1962.

(11) Pierre Thevennaz, What is Phenomenology? (ed.), James M., Edie, Quadrangle Books Inc., Chicago, 1962

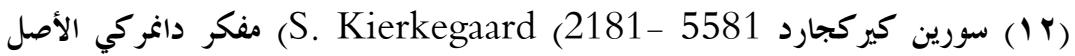

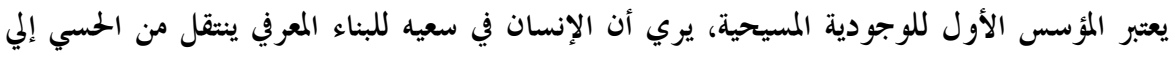

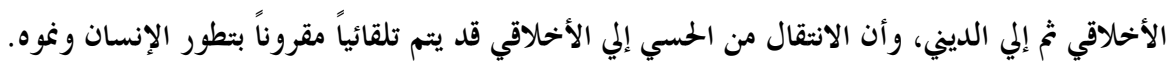


أما الانتقال من الأخلاقي إلي الديني، فلا تتم إلا بواسطة قفزة عاطفية هائلة إلي الجهول، يلتمس فيها الإنسان أن يكون بين يدي الله... ويؤمن به.

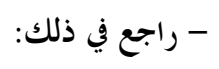

- علي عبد المعطي محمد، سورين كيركجارد : مؤسس الوجودية المسيحية، دار المعرفة الجامعية، الطبعة الثانية، اجه •م، الإسكندرية.

(13) David M., Rasmussem, Mythic - Symbolic Language and Philosophical Anthropology: A Constructive Interpretation of the Thought of Paul Ricoeur, Martinus Nijhoff, The Hague, Netherlands, 1971 , pp. $51-59$.

- والمعروف أن ديفيد راسموسين قد حصل علي درجة الدكتوراه في الفلسفة من جامعة شيكاغو

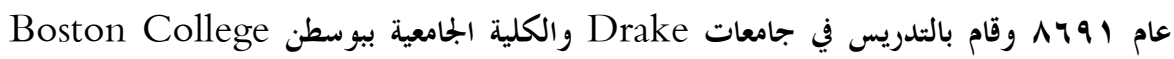

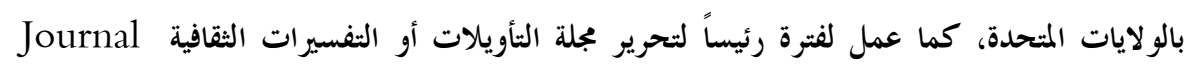
.Cultural Hermeneutics

(14) Ibid., pp. 87 - 91.

(15) Paul Ricoeur, Freedom and Nature, Op. cit., p. 397.

$$
\text { (14) - (14) - (1) أنظر في ذلك: }
$$

-Paul Ricoeur, Fallible Man, Translated by : Charles Kelbley, Henry Regenry, Co Chicago, 1965, pp. $74-78$.

(17) Paul Ricoeur, Freedom and Nature, Op. cit., p. 86

(1) سليمان مظهر، أساطير فمن الشرق، الألف كتاب الثاني، الهيئة المصرية العامة للكتاب،

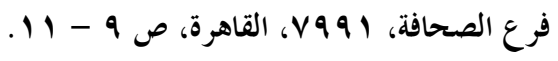

(19) Mircea Eliade, Myth and Reality, Harper and Row, New York, 1963 , p. 64.

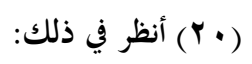

-Paul Ricoeur, The Symbolism of Evil, Op. cit., pp. 164 - 171. 
- محمد حسين دكروب، أنثروبولوجيا الحداثة العربية: منطلقات نقدية، معهد الإنماء العربي،

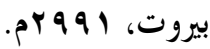

Print to PDF without this message by purchasing novaPDF (http://www.novapdf.com/) 